\title{
Private Equity Portfolio Company Fees
}

\author{
Ludovic Phalippou ${ }^{1}$, Christian Rauch², Marc Umber ${ }^{3}$
}

Online Appendix

Online Appendix A (p. 2): Imputed Fees

Online Appendix B (p. 5): Management Service Agreement Harrah's

Online Appendix C (p. 14): Management Service Agreement HCA

Online Appendix D (p. 24): Management Service Agreement of West Corp.

Online Appendix E (p. 33): Management Service Agreement of Simmons Co. (Deal \#1)

Online Appendix F (p. 39): Management Service Agreement of Simmons Co. (Deal \#2)

Online Appendix G (p. 46): Fee Rebate Rates in Limited Partnership Agreements (LPA)

\footnotetext{
${ }^{1}$ (Corresponding Author) University of Oxford, Saïd Business School. Address: Park End Street, OX1 1HP, Oxford, United Kingdom. Phone: +44 (0)1865 288719. Email: Ludovic.Phalippou@sbs.ox.ac.uk.

${ }^{2}$ American University of Sharjah, School of Business Administration

${ }^{3}$ HighTech Gruenderfonds
} 


\section{Online Appendix A: Imputed fees}

Online Appendix Table 1 shows the different categories our observations can fall into. First we have 371 observations that are exited and with filings in each year. Next, there are 83 observations in total that we include in the complete sample because the missing information they have should not impact our estimate of fees. This include companies for which the missing observations are only in the first and last year of the contractual duration (3), companies for which the missing years are beyond the contractual duration of the fees (8); companies whose fillings stop when they entered chapter 11 (17); and when only the first (19) or last year is missing (36).

There are 19 LBOs with fillings missing in their final years. For these we repeat the last fee charged until the final year of the LBO. $\$ 110$ million gets added, which brings the monitoring fee on these LBOs close to the transaction fee. Since these two fees are overall of the same order of magnitude, this may indicate that our assumption is reasonable. Similarly, 13 LBOs have fillings missing in their early years. We operate as in the previous case and infer $\$ 29$ million of fees.

50 LBOs filed with the SEC only at the time of LBO inception, hence only provided an MSA. 47 are exited and 3 are not exited. As shown in the paper, MSAs contain transaction fees and describe the contractual monitoring fees to be charged. We then assume that the contractual value of monitoring fees was charged in each year of the LBO life and that no termination fee was paid unless the MSA states that a given lump sum payment will be made at termination (7 cases, total of $\$ 45$ million). $\$ 454$ million are added. Again, the sum of monitoring fees after this inference is close although lower than the sum of transaction fees.

The 57 non-exited deals do not get any inferred fees except if they fall in the case just described, or if they have missing fees before the end of our sample. $\$ 168$ million is added. One could rightly argue that non-exited deals have a truncated time-series of fees. Our choice reflects the fact that the on-going deals have all reached the average deal life (four years) and that we lean on the conservative side when inferring fees here and as in previous cases. In total we added $\$ 764$ million. If we use more aggressive assumptions (e.g. assuming they all charged a termination fee) the total would have been about $\$ 1.5$ billion. We think of the $\$ 764$ million as the minimal amount we missed in this incomplete sample. 


\section{Online Appendix Table 1: Imputed Fees}

The Table below summarizes our observations by exit status and SEC coverage.

SEC filling years

Monitoring fees (including termination)

\begin{tabular}{|c|c|c|c|c|c|c|c|}
\hline \multirow[b]{2}{*}{ Status } & & \\
\hline & Early years & Late years & N_obs & $\begin{array}{c}\text { Transaction } \\
\text { Fee }\end{array}$ & Before inference & Amount inferred & $\begin{array}{c}\text { Considered } \\
\text { 'complete' }\end{array}$ \\
\hline Exited & Available & Available & 371 & 5,590 & 4,586 & 0 & Yes \\
\hline Exited & Missing & Missing & 47 & 527 & 62 & 435 & No \\
\hline Exited & Available & Only last year missing & 36 & 1,135 & 733 & 0 & Yes \\
\hline Exited & Available & Missing & 19 & 315 & 161 & 110 & No \\
\hline Exited & Only 1st year missing & Available & 19 & 257 & 402 & 0 & Yes \\
\hline Exited & Available & Missing years during chap 11 protection & 17 & 138 & 55 & 0 & Yes \\
\hline Exited & Missing & Available & 13 & 164 & 77 & 29 & No \\
\hline Exited & Available & Missing years beyond MSA duration & 8 & 66 & 57 & 0 & Yes \\
\hline Exited & Only 1st year missing & Only last year missing & 3 & 140 & 123 & 0 & Yes \\
\hline Exited & Missing & Only last year missing & 2 & 5 & 5 & 3 & No \\
\hline Not exited & Available & Only last year missing & 20 & 783 & 756 & 0 & No \\
\hline Not exited & Available & Available & 18 & 204 & 121 & 0 & No \\
\hline Not exited & Available & Missing & 13 & 456 & 287 & 168 & No \\
\hline Not exited & Missing & Missing & 3 & 38 & 0 & 19 & No \\
\hline Not exited & Available & Missing years beyond MSA duration & 1 & 12 & 20 & 0 & No \\
\hline Not exited & Only 1st year missing & Available & 1 & 70 & 21 & 0 & No \\
\hline \multirow[t]{2}{*}{ Not exited } & Only 1st year missing & Only last year missing & 1 & 16 & 10 & 0 & No \\
\hline & & & 592 & 9,916 & 7,476 & 764 & \\
\hline
\end{tabular}




\section{Online Appendix Table 2: Contractual Rules for Monitoring Fees}

LBOs with a TEV below $\$ 500$ million are classified as small and those above $\$ 500$ million are classified as large. The statistics are derived from the sub-sample of LBOs for which we observed the Management Service Agreement (MSA). All MSAs describe the rule for the calculation of monitoring fees (Panel A) but only a sub-sample provides a duration and termination fee rule. This table gives the relative frequency of each provision in five different samples (all observations, those in 2000 and before, those in 2001 and after, small TEV and large TEV).

Panel A: Rule for the calculation of monitoring fees

\begin{tabular}{|c|c|c|c|c|c|}
\hline & All & Pre2000 & Post2000 & Small & Large \\
\hline Non-growing annuity & 84.1 & 91.3 & 79.3 & 91.2 & 76.9 \\
\hline Growing annuity & 3.5 & 0.6 & 5.6 & 0.4 & 6.7 \\
\hline $1 \%$ of EBITDA & 1.3 & 1.6 & 1.1 & 0.9 & 1.8 \\
\hline $2 \%$ of EBITDA & 1.3 & 0.6 & 1.9 & 0.9 & 1.8 \\
\hline Any $\%$ of sales & 0.4 & 0.6 & 0.4 & 0.4 & 0.4 \\
\hline Greater of Non-growing annuity and $1 \%$ of EBITDA & 2.9 & 0.6 & 4.4 & 0.4 & 5.3 \\
\hline Greater of Non-growing annuity and $2 \%$ of EBITDA & 2.0 & 0.0 & 3.3 & 0.9 & 3.1 \\
\hline Greater of Non-growing annuity and other \% of EBITDA & 0.7 & 0.6 & 0.7 & 0.0 & 1.3 \\
\hline Greater of a Non-growing annuity and any \% of Sales & 3.1 & 4.4 & 2.2 & 4.0 & 2.2 \\
\hline Other & 0.7 & 0.0 & 1.1 & 0.9 & 0.4 \\
\hline
\end{tabular}

Panel B: Duration and termination fees

\begin{tabular}{lccccc}
\hline & All & Pre2000 & Post2000 & Small & Large \\
\hline Duration & & & & & \\
Rolling & & & & & \\
One or three years & 2.4 & 3.3 & 1.8 & 3.2 & 1.6 \\
Five years & 21.2 & 34.8 & 13.5 & 29.4 & 13.2 \\
Six or seven years & 8.2 & 5.4 & 9.8 & 7.1 & 9.3 \\
Ten years & 50.6 & 46.7 & 52.8 & 50.8 & 50.4 \\
Twelve years & 10.2 & 2.2 & 14.7 & 2.4 & 17.8 \\
Other duration & 7.5 & 7.6 & 7.4 & 7.1 & 7.8 \\
& & & & & \\
Fee at Termination calculated as: & & & & & \\
Present Value of Outstanding Fees under Contract & 25.5 & 1.1 & 38.0 & 3.9 & 45.1 \\
Monitoring Fee Survives Contract Termination & 2.6 & 4.4 & 1.7 & 4.7 & 0.7 \\
Other Rule & 8.5 & 5.4 & 10.1 & 5.4 & 11.3 \\
No Explicit Rule Addressing Termination & 51.3 & 72.8 & 40.2 & 71.3 & 33.1 \\
Fee Payments Stop Upon Termination & 12.2 & 16.3 & 10.1 & 14.7 & 9.9 \\
\hline
\end{tabular}




\section{Online Appendix B: Management Service Agreement of Harrah's}

This Services Agreement (the "Agreement") is entered into as of January 28, 2008, by and among Harrah's Entertainment, Inc., a Delaware corporation (the "Company"), Apollo Management VI, L.P., on behalf of affiliated investment funds ("Apollo Management"), Apollo Alternative Assets, L.P. ("Apollo Alternative," and, together with Apollo Management, "Apollo") and TPG Capital, L.P. ("TPG," and, together with Apollo, the "Managers"). WHEREAS, pursuant to an Agreement and Plan of Merger, dated as of December 19, 2006, by and among Hamlet Holdings LLC, a Delaware limited liability company, Hamlet Merger Inc., a Delaware corporation and a wholly owned subsidiary of Hamlet Holdings LLC, and the Company (as amended, the "Merger Agreement"), Hamlet Merger Inc. has been merged with and into the Company (the "Merger") with the Company surviving such merger; WHEREAS, certain investment funds affiliated with Apollo and TPG (collectively, the "Funds") are making an equity investment in the Company in connection with the Merger; and WHEREAS, the Company wishes to retain the Managers to provide certain management and advisory services to the Company, and the Managers are willing to provide such services on the terms set forth below. NOW, THEREFORE, in consideration of the mutual covenants contained herein, the parties hereto, intending to be legally bound, hereby agree as follows:

1. Services. Each Manager hereby severally agrees that, during the term of this Agreement (the "Term"), it will provide to the Company, to the extent requested by the Company and mutually agreed by the Company and each Manager, by and through itself and/or such Manager's successors, assigns, affiliates, officers, partners, directors, employees, agents and/or representatives and third parties (collectively hereinafter referred to as the "Manager Designees"), as such Manager in its sole discretion may designate from time to time, management, advisory and consulting services in relation to the affairs of the Company; provided that the responsibilities of one Manager shall not be substantially disproportionate to the responsibilities of any other Manager. The Company shall request such services by way of written notice to the Managers, which notice shall specify the services required of the Managers and shall include all background material necessary for the Managers to complete such services. Such management, advisory and consulting services shall include, without limitation:

(a) advice in connection with the negotiation and consummation of agreements, contracts, documents and instruments necessary to provide the Company with financing on terms and conditions satisfactory to the Company and its respective subsidiaries; (b) advice in connection with acquisition, disposition and change of control transactions involving the Company or its subsidiaries; (c) financial, managerial and operational advice in connection with operations, including, without limitation, advice with respect to the development and implementation of strategies for improving the operating, marketing and financial performance of the Company or its subsidiaries; and (d) such other services (which may include financial and strategic planning and analysis, consulting services, human resources and executive recruitment services and other services) as the Managers and the Company may from time to time agree in writing.

The Managers or the Manager Designees will devote such time and efforts to the performance of the services contemplated hereby as the Managers deem reasonably necessary or appropriate; provided, however, that no minimum number of hours is required to be devoted by the Managers or the Manager Designees on a weekly, monthly, annual or other basis. The Company acknowledges that each of the services are not exclusive to the Company or its subsidiaries and that the Managers and the Manager Designees may render similar services to other 
persons and entities. The Managers and the Company understand that the Company or its subsidiaries or affiliates (other than the Managers or their affiliates) may at times engage one or more financial advisor, consultant, investment bankers or financial advisers or similar agents to provide services in addition to, but not in lieu of, services provided by the Managers and the Manager Designees under this Agreement. In providing services to the Company or its subsidiaries, the Managers and Manager Designees will act as independent contractors and it is expressly understood and agreed that this Agreement is not intended to create, and does not create, any partnership, agency, joint venture or similar relationship and that no party has the right or ability to contract for or on behalf of any other party or to effect any transaction for the account of any other party.

\section{Payment of Fees.}

(a) As consideration to the Managers for their agreement to render the services in Section 1, on the date hereof, the Company will pay to the Managers (or their respective Manager Designees) an aggregate transaction fee equal to $\$ 200,000,000$ (two hundred million dollars) (the "Transaction Fee"). The Transaction Fee will be divided among the Managers as follows: (i) Apollo or its designee will be entitled to $50 \%$ and (ii) TPG or its designee will be entitled to $50 \%$. Neither Manager nor any of their respective affiliates shall be paid any separate fee in connection with the Merger other than the fees contemplated by this Agreement. In addition to the Transaction Fee, on the date hereof, the Company will pay to the Managers (or their respective Manager Designees), upon obtaining the unanimous consent of the Managers as to the amounts to be paid, an amount equal to all out-of pocket expenses incurred by or on behalf of Hamlet Holdings LLC and each Manager or their respective affiliates, including, without limitation, (i) the reasonable fees, expenses and disbursements of lawyers, accountants, consultants and other advisors that may have been retained by the Company and/or any Manager or its affiliates and (ii) any fees (including any financing fees) related to the Merger (all such fees and expenses, in the aggregate, the "Covered Costs"). (b) During the Term, the Company will pay to the Managers (or their respective Manager Designees) an annual monitoring fee equal to the greater of $(x) \$ 30$ million and (y) 1.0\% (one percent) of the Company's EBITDA (as defined below) (the "Monitoring Fee") as compensation for the services provided by the Managers or the Manager Designees under this Agreement, with such fee being payable by the Company (including the method and timing of payment) as reasonably determined and mutually agreed to by Apollo, TPG and the Company; provided that the Monitoring Fee shall be payable in respect of the period from the date of consummation of the Merger through the end of the calendar quarter during which such consummation occurs shall be pro rated based on the number of days in such period; provided, further, that the Managers or Manager Designees may, with the unanimous consent of the Managers, pay, or cause Merger Sub to pay, any portion of the Monitoring Fee to any third-party in respect of services provided from time to time by such third party to the Company. The Managers or Manager Designees retain the right to defer any portion of the Monitoring Fee without waiving the right to receive such payment at a future date. For purposes of calculating the Monitoring Fee, "EBITDA" shall have the meaning set forth in the credit agreement, dated January 28, 2008, by and among the Company and the other parties thereto (the "Credit Agreement"), as applied to the Company and its Subsidiaries on a consolidated basis. (c) During the Term, in addition to the fees paid pursuant to Section 2(b), the Company will pay to the Managers (or their respective Manager Designees) an aggregate fee (the "Subsequent Fee") in connection with the consummation of any financing or refinancing (equity or debt), dividend, recapitalization, acquisition, disposition, spin-off or split-off transactions involving the Company or any of its direct or indirect subsidiaries equal to customary fees charged by internationally-recognized investment banks for serving as a financial advisor in similar transactions, such fee to be due and payable for the foregoing services at the closing of such transaction. 
(d) Each payment made pursuant to this Section 2 shall be paid by wire transfer of immediately available federal funds to the accounts specified on Schedule 1 hereto, or to such respective other account(s) as the respective Managers may specify to the Company in writing prior to such payment. Each payment made pursuant to this Section 2 (other than the Covered Costs) shall be allocated among the Managers (or their respective Manager Designees) as follows: (i) Apollo will be entitled to 50\%; and (ii) TPG will be entitled to 50\%; provided that such allocation shall be adjusted on the date on which payment is due under this Section 2 to reflect any transfers of Company Shares (as defined in the Stockholders' Agreement) owned by the Sponsor (as defined in the Stockholders' Agreement) affiliated with a Manager and following the date hereof (such Manager, a "Transferring Manager"), other than ( $x$ ) transfers to affiliates of such Transferring Manager or ( $y$ ) pro rata transfers by both Sponsors (such allocation, as adjusted from time to time, the "Allocation Percentage"). For the avoidance of doubt, upon a transfer giving rise to an adjustment pursuant to the preceding sentence (i) the Transferring Manager's Allocation Percentage shall be equal to ( $x$ ) the number of Company Shares held by the Sponsor affiliated with such Transferring Manager after giving effect to the transfer over $(y)$ the total number of Company Shares held by both Sponsors after giving effect to such transfer, and (ii) the Allocation Percentage of the non-Transferring Manager shall be equal to $100 \%$ minus the Transferring Manager's Allocation Percentage determined in clause (i) above. (e) Each payment made to a Manager pursuant to this Section 2 shall be received in respect of the Affiliates of such Manager investing in the Company as provided by such Manager in writing to the Company prior to such payment.

3. Deferral. In the event that any financing or similar agreements to which the Company is a party and that have been approved by both Sponsors in accordance with the Stockholders' Agreement (the "Financing Documents") restrict the payment of all or any portion of any fee payable to the Managers (or their respective Manager Designees) pursuant to Section 2 above for any payment period (such restricted fees, the "Deferred Fees"), the amount of fees paid to each Manager and Manager Designee in such period will be reduced pro rata (based on aggregate fees payable to each such Manager or their respective Manager Designee), and any Deferred Fees will accrue in the immediately succeeding period in which such amounts could, consistent with the Financing Documents, be paid, and will be paid in such succeeding period (in addition to such other amounts that would otherwise be payable at such time) in the manner set forth in Section 2.

4. Term. This Agreement will continue in full force and effect until the last day of the quarter in which the tenth anniversary of the consummation of the Merger occurs; provided that this Agreement shall be automatically extended each December 31 for an additional year unless the Managers (acting unanimously) or the Company provide written notice of their desire not to automatically extend the term of this Agreement to the other parties hereto at least ninety (90) days prior to such December 31; provided, further, that $(x)$ this Agreement may be terminated at any time upon unanimous consent of the Managers and $(\mathrm{y})$ this Agreement shall terminate automatically immediately prior to the earlier of (i) an Initial Public Offering (as defined in the Stockholders' Agreement) or (ii) a transfer or issuance of equity securities of the Company (including by way of a merger, consolidation, amalgamation, share exchange or other form of similar business combination), in a single or series of related transactions, resulting in a Person or Persons other than the existing stockholders owning, directly or indirectly, a majority of the voting power of the applicable Company, upon the consummation of such transfer or issuance, or the sale of all or substantially all of the assets of the Company (any such sale transaction, a "Sale"), in each case, unless otherwise agreed by both Managers, and without any further action by the Company or Apollo or TPG, (i) each of the Company, Apollo and TPG shall be released from any and all obligations and liabilities with respect to provision of the management, 
advisory and consulting services pursuant to this Agreement and payment of the Transaction Fee, the Monitoring Fee, the Subsequent Fee or any other fees pursuant to this Agreement (other than any unreimbursed expenses of Apollo or TPG owing and payable pursuant to Section 5(a)), and this Agreement, other than Section 4 through Section 14, shall have no further force or effect and (ii) in consideration of the termination provided in clause (i), the Company shall pay to each Manager (or their respective Manager Designees), via wire transfer of immediately available funds payable immediately prior to either of an Initial Public Offering or Sale, as the case may be, a lumpsum amount equal to the net present value of the remaining Transaction Fee, the Monitoring Fee, the Subsequent Fee or any other fees pursuant to this Agreement owing and payable by the Company to such Manager (or its Manager Designees) from the date of such Initial Public Offering or Sale, as the case may be, until the expiration of the term of this Agreement (which amount shall be determined using an annual discount rate equal to the thencurrent rate of interest on the Company's revolving credit facility, and assuming that EBITDA would have grown at a rate equal to the greater of $(x) 6 \%$, compounded annually and $(y)$ the compounded annual EBITDA growth rate for the last two completed fiscal years). In the event of an Initial Public Offering or Sale that, in either case, includes noncash consideration, each Manager may elect for it or its Manager Designees to receive all or any portion of any amounts payable pursuant to this Agreement as a result of such Initial Public Offering or Sale in the form of such noncash consideration, valued at the sale price.

5. Expenses; Indemnification.

(a) Expenses. The Company will pay to the Managers (or their respective Manager Designees) on demand all Reimbursable Expenses whether incurred prior to or following the date of this Agreement. As used herein, "Reimbursable Expenses" means (i) all out-of-pocket expenses incurred following the consummation of the Merger relating to the services provided by the Managers, their respective affiliates, or the Manager Designees to the Company or any of its affiliates from time to time (including, without limitation, all air travel (by first class on a commercial airline or by charter, as determined by the Managers or the Manager Designees) and other travel related expenses), (ii) all out-of-pocket legal expenses incurred by the Managers, their respective affiliates or the Manager Designees in connection with the enforcement of rights or taking of actions under this Agreement, the Merger Agreement or any related documents or instruments, whether incurred prior to or following the date of this Agreement, and (iii) all expenses incurred by the Managers, their respective affiliates or the Manager Designees which are properly allocable to the Company, including in connection with their management and operations, whether incurred prior to or following the date of this Agreement. (b) Indemnity and Liability. The Company will indemnify, exonerate and hold the Managers, the Manager Designees and each of their respective partners, shareholders, members, affiliates, associated investment funds, directors, officers, fiduciaries, managers, controlling persons, employees and agents and each of the partners, shareholders, members, affiliates, associated investment funds, directors, officers, fiduciaries, managers, controlling persons, employees and agents of each of the foregoing (collectively, the "Indemnitees") free and harmless from and against any and all actions, causes of action, suits, claims, liabilities, losses, damages and costs and out-of-pocket expenses in connection therewith (including attorneys' fees and expenses) incurred by the Indemnitees or any of them before or after the date of this Agreement (collectively, the "Indemnified Liabilities"), arising out of any action, cause of action, suit, arbitration, investigation or claim arising out of, or in any way relating to (i) this Agreement, the Merger Agreement, any transaction to which the Company is a party or any other circumstances with respect to the Company or (ii) operations of, or services provided by the Managers or the Manager Designees to, the Company, or any of their respective affiliates from time to time; provided that the foregoing indemnification rights will not be available to the extent that any such Indemnified 
Liabilities arose on account of such Indemnitee's willful misconduct; and provided, further, that if and to the extent that the foregoing undertaking may be unavailable or unenforceable for any reason, the Company hereby agrees to make the maximum contribution to the payment and satisfaction of each of the Indemnified Liabilities which is permissible under applicable law. For purposes of this Section 5(b), none of the circumstances described in the limitations contained in the two provisos in the immediately preceding sentence will be deemed to apply absent a final non-appealable judgment of a court of competent jurisdiction to such effect, in which case to the extent any such limitation is so determined to apply to any Indemnitee as to any previously advanced indemnity payments made by the Company, then such payments will be promptly repaid by such Indemnitee to the Company without interest. The rights of any Indemnitee to indemnification hereunder will be in addition to any other rights any such person may have under any other agreement or instrument referenced above or any other agreement or instrument to which such Indemnitee is or becomes a party or is or otherwise becomes a beneficiary or under law or regulation.

6. Disclaimer and Limitation of Liability; Opportunities.

(a) Disclaimer; Standard of Care. None of the Managers nor any of their respective Manager Designee makes any representations or warranties, express or implied, in respect of the services to be provided by the Managers or the Manager Designees hereunder. In no event will the Managers, the Manager Designees or Indemnitees be liable to the Company or any of its affiliates for any act, alleged act, omission or alleged omission that does not constitute willful misconduct of the Managers or the Manager Designees as determined by a final, non-appealable determination of a court of competent jurisdiction. (b) Freedom to Pursue Opportunities. In recognition that the Managers, the Manager Designees and their respective Indemnitees currently have, and will in the future have or will consider acquiring, investments in numerous companies with respect to which the Managers, the Manager Designees or their respective Indemnitees may serve as an advisor, a director or in some other capacity, and in recognition that each Manager, each Manager Designee and their respective Indemnitees have myriad duties to various investors and partners, and in anticipation that the Company on the one hand and each Manager and Manager Designee (or one or more of their respective Indemnitees or portfolio companies), on the other hand, may engage in the same or similar activities or lines of business and have an interest in the same areas of corporate opportunities, and in recognition of the benefits to be derived by the Company hereunder and in recognition of the difficulties which may confront any advisor who desires and endeavors fully to satisfy such advisor's duties in determining the full scope of such duties in any particular situation, the provisions of this Section 6(b) are set forth to regulate, define and guide the conduct of certain affairs of the Company as they may involve the Managers, the Manager Designees or their respective Indemnitees. Except as the Managers or the Manager Designees, may otherwise agree in writing after the date hereof: (i) The Managers, the Manager Designees and their respective Indemnitees will have the right: $(A)$ to directly or indirectly engage in any business (including, without limitation, any business activities or lines of business that are the same as or similar to those pursued by, or competitive with, the Company and its subsidiaries), (B) to directly or indirectly do business with any client or customer of the Company or its subsidiaries, (C) to take any other action that a Manager or a Manager Designee believes in good faith is necessary to or appropriate to fulfill its obligations as described in the first sentence of this Section 6(b), (D) not to communicate or present potential transactions, matters or business opportunities to the Company or any of its subsidiaries, and to pursue, directly or indirectly, any such opportunity for itself, and to direct any such opportunity to another Person, and $(E)$ to take any other action permitted pursuant to Section 6.02 of the Stockholders' Agreement or Article XII of the amended and restated certificate of incorporation of the Company. (ii) Except as provided in Section 6(a), none of the Managers, the Manager Designees nor any of their respective Indemnitees will be liable to 
the Company or any of its affiliates for breach of any duty (contractual or otherwise) by reason of any activities or omissions of the types referred to in this Section 6(b) or of any such Person's participation therein. (c) Limitation of Liability. In no event will a Manager, a Manager Designee or any of their respective Indemnitees be liable to the Company or any of its affiliates for any indirect, special, incidental or consequential damages, including, without limitation, lost profits or savings, whether or not such damages are foreseeable, or for any third party claims (whether based in contract, tort or otherwise), relating to the services to be provided by a Manager or a Manager Designee hereunder.

7. Assignment, etc. Except as provided below, none of the parties hereto will have the right to assign this Agreement without the prior written consent of each of the other parties. Notwithstanding the foregoing, (a) each Manager may assign all or part of its rights and obligations hereunder to any of its respective affiliates that provides services similar to those called for by this Agreement, in which event such Manager will no longer be entitled to any fees under Section 2 and reimbursement of expenses under Section 2(a) and Section 5(a) and will be released of all of its obligations hereunder and (b) the provisions hereof for the benefit of Indemnitees of the Managers will inure to the benefit of such Indemnitees and their successors and assigns.

8. Amendments and Waivers. No amendment or waiver of any term, provision or condition of this Agreement will be effective, unless given in writing by both Managers and executed by the Company; provided that any Manager may waive any portion of any fee to which it is entitled pursuant to this Agreement, and, unless otherwise directed by the Manager, such waived portion will revert to the Company. No waiver on any one occasion will extend to or effect or be construed as a waiver of any right or remedy on any future occasion. No course of dealing of any person nor any delay or omission in exercising any right or remedy will constitute an amendment of this Agreement or a waiver of any right or remedy of any party hereto.

9. Governing Law; Jurisdiction. THIS AGREEMENT SHALL BE GOVERNED AND CONSTRUED IN ACCORDANCE WITH THE LAWS OF THE STATE OF DELAWARE, WITHOUT REGARD TO THE CONFLICTS OF LAW PRINCIPLES THEREOF. ANY ACTION OR PROCEEDING AGAINST THE PARTIES RELATING IN ANY WAY TO THIS AGREEMENT MAY BE BROUGHT AND ENFORCED EXCLUSIVELY IN THE COURTS OF THE STATE OF DELAWARE OR (TO THE EXTENT SUBJECT MATTER JURISDICTION EXISTS THEREFOR) THE UNITED STATES DISTRICT COURT FOR THE SOUTHERN DISTRICT OF NEW YORK SITTING IN MANHATTAN, AND THE PARTIES IRREVOCABLY SUBMIT TO THE JURISDICTION OF BOTH SUCH COURTS IN RESPECT OF ANY SUCH ACTION OR PROCEEDING.

10. WAIVER OF JURY TRIAL. BECAUSE DISPUTES ARISING IN CONNECTION WITH COMPLEX FINANCIAL TRANSACTIONS ARE MOST QUICKLY AND ECONOMICALLY RESOLVED BY AN EXPERIENCED AND EXPERT PERSON AND THE PARTIES WISH APPLICABLE STATE AND FEDERAL LAWS TO APPLY (RATHER THAN ARBITRATION RULES), THE PARTIES DESIRE THAT THEIR DISPUTES BE RESOLVED BY A JUDGE, APPLYING SUCH APPLICABLE LAWS. THEREFORE, TO ACHIEVE THE BEST COMBINATION OF THE BENEFITS OF THE JUDICIAL SYSTEM, THE PARTIES HERETO WAIVE ALL RIGHT TO TRIAL BY JURY IN ANY ACTION, SUIT OR PROCEEDING BROUGHT TO ENFORCE OR DEFEND ANY RIGHT OR REMEDIES UNDER THIS AGREEMENT OR ANY DOCUMENTS ENTERED INTO IN CONNECTION WITH THIS AGREEMENT AND

THE TRANSACTIONS CONTEMPLATED HEREIN. The Company or any Manager may file an original counterpart or 
a copy of this Section 10 with any court as written evidence of the consent of the parties to the waiver of their rights to trial by jury.

11. Entire Agreement. This Agreement contains the entire understanding of the parties with respect to the subject matter hereof and supersedes any prior communication or agreement with respect thereto.

12. Notice. Unless otherwise specified herein, all notices, consents, approvals, reports, designations, requests, waivers, elections and other communications authorized or required to be given pursuant to this Agreement shall be in writing and shall be given or made (and shall be deemed to have been duly given or made upon receipt) by personal hand-delivery, by facsimile transmission, by electronic mail, by mailing the same in a sealed envelope, registered first-class mail, postage prepaid, return receipt requested, or by air courier guaranteeing overnight delivery, sent to the Stockholders at the following addresses (or such other address as such Stockholders may specify by notice to the Company:

If to the Company (with a copy, which shall not constitute notice, to Apollo and TPG), to:

One Caesars Palace Drive

Las Vegas, NV 89109

Attention: Steve Brammell

Telephone: 702-407-6393

Fax: 702-407-6418

with a copy to each of (which shall not constitute notice):

Cleary Gottlieb Steen \& Hamilton LLP

One Liberty Plaza

New York, NY 10006

Attention: Paul J. Shim, Esq.

Telephone: 212.225.2930

Fax: 212.225.3999

Wachtell, Lipton, Rosen \& Katz

51 West 52nd Street

New York, New York 10019

Attention: Steven A. Cohen, Esq., Gregory E. Ostling, Esq.

Telephone: 212.403 .1000

Facsimile: 212.403 .2000

If to Apollo Management, to:

Apollo Management VI, L.P.

9 West 57th Street

New York, NY 10019

Attention: Eric L. Press

Facsimile: 212.515.3288

with a copy (which shall not constitute notice) to:

Wachtell, Lipton, Rosen \& Katz 
51 West 52nd Street

New York, NY 10019

Attention: Steven A. Cohen, Gregory E. Ostling

Facsimile: 212.403-2364

If to Apollo Alternative, to:

Apollo Alternative Assets, L.P.

c/o Apollo Management VI, L.P.

9 West 57th Street

New York, NY 10019

Attention: Eric L. Press

Facsimile: 212.515.3288

with a copy (which shall not constitute notice) to:

Wachtell, Lipton, Rosen \& Katz

51 West 52nd Street

New York, NY 10019

Attention: Steven A. Cohen, Gregory E. Ostling

Facsimile: 212.403-2364

If to TPG, to:

TPG Capital, L.P.

301 Commerce Street

Suite 3300

Fort Worth, Texas 76102

Attention: Clive D. Bode

Facsimile: (817) 871-4088

with a copy (which shall not constitute notice) to:

Cleary Gottlieb Steen \& Hamilton LLP

One Liberty Plaza

New York, NY 10006

Attention: Paul J. Shim

Facsimile: (212) 225-3999

13. Severability. If any provision of this Agreement shall be held to be invalid, illegal or unenforceable, the validity, legality and enforceability of the remaining provisions shall not in any way be affected or impaired thereby.

14. Counterparts. This Agreement may be executed in any number of counterparts, each of which shall be deemed an original, but all of which shall constitute one and the same instrument.

IN WITNESS WHEREOF, the parties hereto have executed this Agreement as of the day and year first above written.

HARRAH'S ENTERTAINMENT, INC. 
By: /s/ Anthony Civale

Name: Anthony Civale

Title: Director

APOLLO MANAGEMENT VI, L.P.

on behalf of affiliated investment funds

By: AIF VI Management, LLC, its general partner

By: /s/ Laurie Medley

Name: Laurie Medley

Title: Vice President

APOLLO ALTERNATIVE ASSETS, L.P.

By: Apollo Alternative Assets GP Limited, its general partner

By: /s/ Laurie Medley

Name: Laurie Medley

Title: Vice President

TPG CAPITAL, L.P.

By: Tarrant Capital, LLC, its general partner

By: /s/ Clive D. Bode

Name: Clive D. Bode

Title: Vice President 


\section{Online Appendix C: Management Service Agreement of HCA}

This Management Agreement (this "Agreement") is entered into as of November 17, 2006 by and among HCA Inc., a Delaware corporation (the "Company"), Bain Capital Partners, LLC ("Bain”), Kohlberg Kravis Roberts \& Co. L.P. ("KKR"), Dr. Thomas F. Frist, Jr., Patricia F. Elcan, William R. Frist and Thomas F. Frist III (each, a "Frist" and collectively, "Frist") ("Frist") and Merrill Lynch Global Partners, Inc. ("ML" and together with Bain, KKR and each Frist, the "Managers"), provided that each such entity shall cease to be a "Manager" for all purposes hereunder at such time as investment funds affiliated with or Affiliated Entities of such Manager are no longer entitled to designate any members of the Board of Managers of Hercules Holding II, LLC ("LLC"). Certain capitalized terms used herein are specifically defined in Section 6.

WHEREAS, each of LLC and Hercules Acquisition Corporation, a Delaware corporation ("Hercules Acquisition"), has been formed for the purpose of engaging in a transaction in which Hercules Acquisition will be merged with and into the Company, with the Company surviving (the "Merger"), pursuant to an Agreement and Plan of Merger between Hercules Acquisition, the Company and LLC dated as of July 24, 2006 (as amended from time to time, the "Merger Agreement"). WHEREAS, to enable Hercules Acquisition to engage in the Merger and related transactions, the Managers provided financial and structural advice and analysis as well as assistance with due diligence investigations and negotiations (the "Financial Advisory Services"); and WHEREAS, the Company wants to retain the Managers to provide certain management, consulting and advisory services to the Company, and the Managers are willing to provide such services, on the terms set forth below. NOW THEREFORE, in consideration of the mutual covenants contained herein, the parties hereto, intending to be legally bound, hereby agree as follows:

1. Services. Each of the Managers hereby agrees that, during the term of this Agreement (the "Term"), it will provide the following management, consulting and financial and other advisory services to the Company as requested from time to time by the Board of Directors of the Company: (a) advice in connection with the negotiation of agreements, contracts, documents and instruments relating to the Company's financing; (b) financial, managerial and operational advice in connection with the Company's business, including, without limitation, advice with respect to the development and implementation of strategies for improving the operating and financial performance of the Company and its subsidiaries; and (c) advice in connection with financing, acquisition, disposition, merger, combination or change of control transactions involving the Company or any of its subsidiaries (however structured). (d) such other services (which may include financial and strategic planning and analysis, consulting services, human resources and executive recruitment services and other services) as such Manager and the Company may from time to time agree in writing.

Each of the Managers shall devote such time and efforts to the performance of services contemplated hereby as such Manager deems reasonably necessary or appropriate; provided, however, that no minimum number of hours is required to be devoted by Bain, KKR, ML or each Frist on a weekly, monthly, annual or other basis. The Company acknowledges that each of the Managers' services are not exclusive to the Company and that each Manager will render similar services to other persons and entities. The Managers and the Company understand that the Company may, at times, engage one or more investment bankers or financial advisers to provide services in addition to, but not in lieu of, services provided by the Managers under this Agreement. In providing services to the Company, each Manager will act as an independent contractor and it is expressly understood and agreed that this Agreement is not 
intended to create, and does not create, any partnership, agency, joint venture or similar relationship and that no party has the right or ability to contract for or on behalf of any other party or to effect any transaction for the account of any other party.

\section{Payment of Fees.}

(a) The Company will pay to the Managers (or such affiliates as they may respectively designate), in consideration of the Managers providing the Financial Advisory Services, an aggregate transaction fee (the "Transaction Fee") in the amount of $\$ 175,000,000$, such fee being payable at the closing of the Merger. The Transaction Fee shall be divided among the Managers as follows:

Bain: $\$ 48,611,111.11$

KKR: $\$ 48,611,111.11$

$\mathrm{ML}: \$ 48,611,111.11$

Frist $^{4}: \$ 29,166,666.67$

(b) During the Term, the Company will pay to the Managers (or such affiliates as they may respectively designate), an annual fee (the "Periodic Fee") of $\$ 15,000,000$, such fee to be increased annually at a rate equal to the Percentage Increase in Adjusted EBITDA over the previous year, effective as of March 31 of each such year, (the first such increase to be effective March 31, 2008) in exchange for the ongoing services provided by the Managers under Section 1 of this Agreement, such fee being payable by the Company in equal quarterly installments in arrears at the end of each calendar quarter. The initial quarterly Periodic Fee payment shall be pro rated to reflect the portion of the current fiscal quarter that will elapse after the Merger. The final quarterly Periodic Fee payment shall be pro rated to reflect the portion of the final quarter prior to the end of the Term. The Periodic Fee shall initially be divided among the Managers as follows: $3 / 15$ ths to Frist ${ }^{5}$ and 4/15ths to each of Bain, KKR and ML. The allocation of the Periodic Fee shall be appropriately adjusted in the event of any changes to the proportion of the number of Shares owned in the aggregate by each Manager and its Affiliated Entities (directly, or indirectly through their holdings of units of the LLC) on the last business day in the applicable calendar quarter for which such Periodic Fee is required to be paid (provided that, for purposes of this Agreement, (i) the Bain Group and their respective Affiliated Entities shall be deemed to be investment funds affiliated with Bain; (ii) the KKR Group and their respective Affiliated Entities shall be deemed to be investment funds affiliated with KKR, (iii) the ML Group and their respective Affiliated Entities shall be deemed to be investment funds affiliated with ML; and (iv) the Family Group and their respective Family Affiliates shall be deemed to be investment funds affiliated with Frist). (c) The Company will, for each financing, acquisition, disposition, merger, combination or change of control transaction involving the Company or any of its subsidiaries (however structured), which has a gross transaction value of at least $\$ 100,000,000$, pay to the Managers (or such affiliates as they may respectively designate) an aggregate fee (the "Subsequent Fee") in connection with each such transaction equal to one percent $(1 \%)$ of the gross transaction value (including the purchase price paid (whether in cash or other property) and all liabilities assumed or otherwise included in the transaction) of such transaction or such other amount as may be mutually agreed by the Company and the Requisite Members, such fee to be due and payable for the foregoing services at the closing of such transaction and, in the case of financing transactions,

\footnotetext{
${ }^{4}$ To be allocated as follows: (i) Thomas F. Frist, Jr.: \$10,496,208.33; (ii) Patricia F. Elcan: 6,117,416.67; (iii) Thomas F. Frist III: $\$ 4,503,800.00$ and (iv) William R. Frist: $\$ 8,049,241.67$.

${ }^{5}$ To be allocated to each Frist, in consideration of each Frist providing the ongoing services provided by the Managers under Section 1 as follows: (i) Thomas F. Frist, Jr.: 35.987023\%; (ii) Patricia F. Elcan: 20.974009\%; (iii) Thomas F. Frist III: 15.441588\% and (iv) William R. Frist: $27.597380 \%$.
} 
whether or not any such financing is actually committed or drawn upon. Each Subsequent Fee shall be divided among the Managers in the same proportion as the Periodic Fee would be apportioned if the date such Subsequent Fee is required to be paid were the last business day of a quarter.

3. Term. This Agreement shall continue in full force and effect until December 31, 2016; provided that this Agreement shall be automatically extended each December 31 for an additional year unless the Company or the Requisite Members provide written notice of their desire not to automatically extend the term of this Agreement to the other parties hereto at least 90 days prior to such December 31; provided, however, (a) that the Requisite Members may cause this Agreement to terminate at any time and (b) this Agreement shall terminate automatically immediately upon the consummation of an initial public offering unless the Requisite Members determine otherwise. In the event of a termination of this Agreement, the Company shall pay each of the Managers (or such affiliates as they may respectively designate) (i) all unpaid Periodic Fees (pursuant to Section 2(b) above), Subsequent Fees (pursuant to Section 2(c) above) and expenses (pursuant to Section 4(a) below) due with respect to periods prior to the date of termination plus (ii) the sum of the net present values (using discount rates equal to the then yield on U.S. Treasury Securities of like maturity) of the Periodic Fees that would have been payable with respect to the period from the date of termination until the expiration date in effect immediately prior to such termination. The amounts described in clause (ii) above shall be divided among the Managers in the same proportion as the Periodic Fee would be apportioned if the applicable termination date were the last business day of a quarter. Sections 4 and 5 of this Agreement and any and all accrued and unpaid obligations under Section 2 shall survive any termination of this Agreement with respect to matters occurring before, on or after the date of such termination.

\section{Expenses; Indemnification}

(a) Expenses. The Company will pay on demand all Reimbursable Expenses. As used herein, "Reimbursable Expenses" means (i) all expenses incurred or accrued prior to the date on which the transactions contemplated by the Merger Agreement are consummated (the "Closing Date") by any of the Managers or their affiliates (including, in the case of Frist, the Family Group and their respective Family Affiliates) in connection with this Agreement, the Merger or any related transactions, consisting of their respective out-of-pocket expenses for travel and other incidentals in connection with such transactions (including, without limitation, all air travel (by first class on a commercial airline, by charter or by privately owned airplane, as determined by the party seeking reimbursement) and other travel related expenses) and the out-of-pocket expenses and the fees and charges of outside counsel and any other consultants or advisors retained by the Managers in connection with such transactions, (ii) reasonable out-ofpocket expenses incurred from and after the Closing Date relating to their affiliated funds' or Affiliated Entities' investment in, the operations of, or the services provided by the Managers or former Managers to, the Company or any of its affiliates from time to time (including, without limitation, all air travel (by first class on a commercial airline, by charter or by privately owned airplane, as determined by the appropriate Manager or former Manager) and other travel related expenses), provided, however, that the Requisite Members must approve any expenses referred to in this clause (ii) other than routine out-of-pocket expenses (it being understood that expenses of outside counsel incurred by the Managers for advice in the ordinary course regarding the investment, as well as regarding any transactions involving such investment, shall be deemed approved hereunder), and (iii) expenses incurred from and after the Closing Date by the Managers or former Managers, and their affiliates, which the Requisite Members agree are properly allocable to the Company under this Agreement. (b) Indemnity and Liability. The Company will 
indemnify, exonerate and hold each of the Managers and former Managers, and each of their respective partners, shareholders, members, affiliates, directors, officers, fiduciaries, managers, controlling Persons, employees and agents and each of the partners, shareholders, members, affiliates, directors, officers, fiduciaries, managers, controlling Persons, employees and agents of each of the foregoing (collectively, the "Indemnitees") free and harmless from and against any and all actions, causes of action, suits, claims, liabilities, losses, damages and costs and out-of-pocket expenses in connection therewith (including reasonable attorneys' fees and expenses) incurred by the Indemnitees or any of them before or after the date of this Agreement (collectively, the "Indemnified Liabilities"), as a result of, arising out of, or in any way relating to (i) this Agreement, the Merger, any transaction to which the Company is a party or any other circumstances with respect to the Company (other than any such Indemnified Liabilities to the extent such Indemnified Liabilities arise out of any breach of the LLC Agreement or any related agreements by such Indemnitee or its affiliated or associated Indemnitees or any transaction entered into after the Closing Date or (ii) operations of, or services provided by any of the Managers or former Managers to the Company, or any of its affiliates from time to time, whether pursuant to this Agreement or otherwise; provided that the foregoing indemnification rights shall not be available to the extent that any such Indemnified Liabilities arose on account of such Indemnitee's gross negligence or willful misconduct, and further provided that, if and to the extent that the foregoing undertaking may be unavailable or unenforceable for any reason, the Company hereby agrees to make the maximum contribution to the payment and satisfaction of each of the Indemnified Liabilities which is permissible under applicable law. For purposes of this Section 4(b), none of the circumstances described in the limitations contained in the two provisos in the immediately preceding sentence shall be deemed to apply absent a final nonappealable judgment of a court of competent jurisdiction to such effect, in which case to the extent any such limitation is so determined to apply to any Indemnitee as to any previously advanced indemnity payments made by the Company, then such payments shall be promptly repaid by such Indemnitee to the Company. The rights of any Indemnitee to indemnification hereunder will be in addition to any other rights any such person may have under any other agreement or instrument referenced above or any other agreement or instrument to which such Indemnitee is or becomes a party or is or otherwise becomes a beneficiary or under law or regulation. None of the Indemnitees shall in any event be liable to the Company or any of its affiliates for any act or omission suffered or taken by such Indemniee in connection with, relating to or arising out of this Agreement, including without limitation the services provided by such Indemniee to the Company or any of its affiliates (a) that does not constitute gross negligence or willful misconduct or (b) in excess of the fees received by the applicable Manager hereunder. If the Indemnitees related to more than one Manager or former Manager are similarly situated with respect to their interests in connection with a matter that may be an Indemnified Liability and such Indemnified Liability is not based on a ThirdParty Claim, the Indemnitees may enforce their rights pursuant to this Section 4(b) with respect to such matter only with the consent of at least a majority of the Managers or former Managers whose Indemnitees are so involved. In the event that any party that was previously a Manager hereunder ceases to be a Manager in accordance with the definition thereof, the provisions hereof for the benefit of Indemnitees of such party shall inure to such Indemnitees and their successors and assigns.

5. Disclaimer and Limitation of Liability; Opportunities.

(a) Disclaimer; Standard of Care. None of the Managers or former Managers makes any representations or warranties, express or implied, in respect of the services to be provided by any Manager or former Manager hereunder. In no event shall any Manager or former Manager be liable to the Company or any of its affiliates for any act, alleged act, omission or alleged omission that does not constitute gross negligence or willful misconduct of such 
Manager or former Manager as determined by a final, non-appealable determination of a court of competent jurisdiction.

(b) Limitation of Liability. In no event will any of the Managers or former Managers or any of their Indemnitees be liable to the Company or any of its affiliates or either of the other Managers or former Managers or their Indemnitees for any indirect, special, incidental or consequential damages, including, without limitation, lost profits or savings, whether or not such damages are foreseeable, or for any third party claims (whether based in contract, tort or otherwise), relating to, in connection with or arising out of this Agreement, including without limitation the services to be provided by the Managers or former Managers hereunder, or for any act or omission that does not constitute gross negligence or willful misconduct or in excess of the fees received by the applicable Manager hereunder.

6. Definitions. For purposes of this agreement, the following terms shall have the following meanings:

"Adjusted EBITDA" shall have the meaning given to such term in the Indenture dated as of November 17, 2006 between and among the Company, the guarantors listed on the signature pages thereto and The Bank of New York, as trustee, relating to the issuance of the $91 / 8 \%$ Senior Secured Notes due 2014, the $91 / 4$ Senior Secured Notes due 2016 and the 9 5/8\%/10 3/8\% Senior Secured Toggle Notes due 2016. "Affiliated Entities" shall have the same meaning given to it in the LLC Agreement. "Bain Group" shall have the meaning given to such term in the LLC Agreement. "Family Affiliates" shall have the same meaning given to it in the LLC Agreement. "Family Group" shall have the meaning given to such term in the LLC Agreement. "KKR Group" shall have the meaning given to such term in the LLC Agreement. "LLC Agreement" means the Amended and Restated Limited Liability Company Agreement dated November 17, 2006 among Hercules Holding II, LLC and the other parties thereto, as the same may be amended from time to time in accordance with its terms. "Merrill Lynch Group" shall have the meaning given to such term in the LLC Agreement. "Percentage Increase in Adjusted EBITDA" means the amount of increase, expressed as a percentage, of the Adjusted EBITDA for the most recently completed fiscal year as compared to the Adjusted EBITDA of the next most recently completed fiscal year; provided that if there is no such increase, then the "Percentage Increase in Adjusted EBITDA" shall be $0 \%$ for such applicable year. "Person" means any individual or corporation, association, partnership, limited liability company, joint venture, joint stock or other company, business trust, trust, organization, or other entity of any kind. "Requisite Members" shall have the meaning given to such term in the LLC Agreement. "Shares" shall mean the shares of HCA Common Stock (as defined in the LLC Agreement). "Third-Party Claim" means any (i) claim brought by a Person other than the Company, LLC, a Manager or any indemnified Person related to a Manager and (ii) any derivative claim brought in the name of the Company or LLC that is initiated by a Person other than a Manager or any indemnified Person related to a Manager.

7. Assignment, etc. Except as provided below, none of the parties hereto shall have the right to assign this Agreement without the prior written consent of each of the other parties. Notwithstanding the foregoing, (a) any Manager may assign all or part of its rights and obligations hereunder to any of its respective affiliates which provides services similar to those called for by this Agreement, in which event such Manager shall be released of its rights to fees under Section 2 and reimbursement of expenses under Section 4(a) and all of its obligations hereunder, (b) the provisions hereof for the benefit of Indemnitees of the Managers shall inure to the benefit of such Indemnitees and their successors and assigns and (c) all amounts due and owing or payable hereunder to any of the individuals identified in footnote 2 hereof shall be paid when due or owing under the terms hereof to such person's estate ; provided, that, the Company shall have received written notice of such person's death and all amounts that would be 
payable hereunder to any of the individuals identified in footnote 2 hereof shall, after such persons death, be payable pro rata among the other individuals identified in footnote 2.

8. Amendments and Waivers. No amendment or waiver of any term, provision or condition of this Agreement shall be effective, unless in writing and executed by the Requisite Members and the Company; provided, that any amendment or waiver that discriminates against or would adversely affect a Manager will require the consent of such Manager; and provided, further that any Manager may waive any portion of any fee to which it is entitled pursuant to this Agreement, and, unless otherwise directed by such Manager, such waived portion shall revert to the Company. No waiver on any one occasion shall extend to or effect or be construed as a waiver of any right or remedy on any future occasion. No course of dealing of any person nor any delay or omission in exercising any right or remedy shall constitute an amendment of this Agreement or a waiver of any right or remedy of any party hereto.

9. Governing Law: Jurisdiction.

(a) Choice of Law. This Agreement and all matters arising under or related to this Agreement shall be governed by and construed in accordance with the domestic substantive laws of the State of Delaware without giving effect to any choice or conflict of law provision or rule that would cause the application of the domestic substantive laws of any other jurisdiction. (b) Consent to Jurisdiction. Each party to this Agreement, by its execution hereof, (i) hereby irrevocably submits to the exclusive jurisdiction of the state and federal courts sitting in the State of Delaware for the purpose of any action, claim, cause of action or suit (in contract, tort or otherwise), inquiry, proceeding or investigation arising out of or based upon this Agreement or relating to the subject matter hereof, (ii) hereby waives to the extent not prohibited by applicable law, and agrees not to assert, and agrees not to allow any of its subsidiaries to assert, by way of motion, as a defense or otherwise, in any such action, any claim that it is not subject personally to the jurisdiction of the above-named courts, that its property is exempt or immune from attachment or execution, that any such proceeding brought in one of the above-named courts is improper, or that this Agreement or the subject matter hereof or thereof may not be enforced in or by such court and (iii) hereby agrees not to commence or maintain any action, claim, cause of action or suit (in contract, tort or otherwise), inquiry, proceeding or investigation arising out of or based upon this Agreement or relating to the subject matter hereof or thereof other than before one of the above-named courts nor to make any motion or take any other action seeking or intending to cause the transfer or removal of any such action, claim, cause of action or suit (in contract, tort or otherwise), inquiry, proceeding or investigation to any court other than one of the above-named courts whether on the grounds of inconvenient forum or otherwise. Notwithstanding the foregoing, to the extent that any party hereto is or becomes a party in any litigation in connection with which it may assert indemnification rights set forth in this agreement, the court in which such litigation is being heard shall be deemed to be included in clause (i) above. Notwithstanding the foregoing, any party to this Agreement may commence and maintain an action to enforce a judgment of any of the above-named courts in any court of competent jurisdiction. Each party hereto hereby consents to service of process in any such proceeding in any manner permitted by Delaware law, and agrees that service of process by registered or certified mail, return receipt requested, at its address specified pursuant to Section 11 hereof is reasonably calculated to give actual notice. (c) WAIVER OF JURY TRIAL. TO THE EXTENT NOT PROHIBITED BY APPLICABLE LAW WHICH CANNOT BE WAIVED, EACH PARTY HERETO HEREBY WAIVES AND COVENANTS THAT IT WILL NOT ASSERT (WHETHER AS PLAINTIFF, DEFENDANT OR OTHERWISE) ANY RIGHT TO TRIAL BY JURY IN ANY FORUM IN RESPECT OF ANY ISSUE OR ACTION, CLAIM, CAUSE OF ACTION OR SUIT (IN CONTRACT, TORT OR OTHERWISE), INQUIRY, PROCEEDING OR INVESTIGATION ARISING OUT OF OR BASED UPON THIS 
AGREEMENT OR THE SUBJECT MATTER HEREOF OR IN ANY WAY CONNECTED WITH OR RELATED OR INCIDENTAL TO THE TRANSACTIONS CONTEMPLATED HEREBY, IN EACH CASE WHETHER NOW EXISTING OR HEREAFTER ARISING. EACH PARTY HERETO ACKNOWLEDGES THAT IT HAS BEEN INFORMED BY THE OTHER PARTIES HERETO THAT THIS SECTION 9(c) CONSTITUTES A MATERIAL INDUCEMENT UPON WHICH THEY ARE RELYING AND WILL RELY IN ENTERING INTO THIS AGREEMENT AND THE TRANSACTIONS CONTEMPLATED HEREBY. ANY PARTY HERETO MAY FILE AN ORIGINAL COUNTERPART OR A COPY OF THIS SECTION 9(c) WITH ANY COURT AS WRITTEN EVIDENCE OF THE CONSENT OF EACH SUCH PARTY TO THE WAIVER OF ITS RIGHT TO TRIAL BY JURY.

10. Entire Agreement. This Agreement contains the entire understanding of the parties with respect to the subject matter hereof and supersedes any prior communication or agreement with respect thereto.

11. Notice. Any notices and other communications required or permitted in this Agreement shall be in writing and (a) delivered personally, (b) sent by facsimile or e-mail (if provided and the recipient acknowledges receipt thereof by reply e-mail or otherwise), or (c) sent by overnight courier, in each case, addressed as follows:

If to the Company, to it:

HCA Inc.

One Park Plaza

Nashville, Tennessee 37203

Attention: General Counsel

with copies to:

Simpson Thacher \& Bartlett LLP

425 Lexington Avenue

New York, New York 10017

Facsimile: (212) 455-2502

Attention: David Sorkin, Esq.

Email: dsorkin@stblaw.com

If to Bain, to it:

Bain Capital Partners, LLC

111 Huntington Avenue

Boston, Massachusetts 02199

Facsimile: (617) 516-2710

Attention: John Connaughton

E-mail: jconnaughton@baincapital.com

with copies to:

Ropes \& Gray LLP

One International Place

Boston, Massachusetts 02110

Facsimile: (617) 951-7050

Attention: R. Newcomb Stillwell, Esq., Julie H. Jones, Esq. 
E-mail: nstillwell@ropesgray.com, jjones@ropesgray.com

If to KKR, to it:

c/o Kohlberg Kravis Roberts \& Co. L.P.

2800 Sand Hill Road, Suite 200

Menlo Park, CA 94025

Facsimile: (650) 233-6561

Attention: Michael Michelson

E-mail: michm@kkr.com

with copies to:

Simpson Thacher \& Bartlett LLP

425 Lexington Avenue

New York, NY 10017

Facsimile: (212) 455-2502

Attention: David Sorkin, Esq., Sean Rodgers, Esq.

E-mail: dsorkin@stblaw.com, srodgers@stblaw.com

If to $M L$, to it:

c/o Merrill Lynch Global Private Equity

Four World Financial Center, Floor 23

New York, NY 10080

Facsimile: (212) 449-1119

Attention: George A. Bitar, Christopher Birosak

with copies (which shall not constitute notice) to:

c/o Proskauer Rose LLP

1585 Broadway

New York, NY 10036-8299

Facsimile: (212) 969-2900

Attention: James P. Gerkis, Esq., Jeffery A. Horwitz, Esq.

and a copy to:

Merrill Lynch Global Private Equity

Strategic M\&A and Private Equity Counsel

Four World Financial Center, Floor 23

New York, NY 10080

Facsimile: (212) 449-7902

Attention: Frank J. Marinaro, Esq.

If to Frist, to it:

c/o Dr. Thomas F. Frist, Jr.

3100 West End Ave., Suite 500

Nashville, TN 372034

Telecopy: (615) 385-9101 
with copies to:

Sullivan \& Cromwell LLP

125 Broad Street

New York, NY 10004

Attention: John Evangelakos, Esq.

Telecopy: (212) 558-3588

Unless otherwise specified herein, such notices or other communications shall be deemed effective and duly given upon actual receipt (or refusal of receipt). Each of the parties hereto shall be entitled to specify a different address by giving notice as aforesaid to each of the other parties hereto.

12. Severability. In the event that any provision hereof would, under applicable law, be invalid or unenforceable in any respect, such provision shall be construed by modifying or limiting it so as to be valid and enforceable to the maximum extent compatible with, and possible under, applicable law. The provisions hereof are severable, and in the event any provision hereof should be held invalid or unenforceable in any respect, it shall not invalidate, render unenforceable or otherwise affect any other provision hereof.

13. Counterparts. This Agreement may be executed in multiple counterparts, each of which shall be deemed an original, but all of which taken together shall constitute one instrument. A facsimile signature shall be considered due execution and shall be binding upon the signatory thereto with the same force and effect as if the signature were an original.

14. Payments. Each payment made pursuant to Section 2, 3 or 4 shall be paid by wire transfer of immediately available federal funds to the accounts specified to the Company in writing prior to such payment.

IN WITNESS WHEREOF, each of the undersigned has duly executed this Agreement (or caused this Agreement to be executed on its behalf by its officer or representative thereunto duly authorized) under seal as of the date first above written.

HCA INC.

By: /s/ R. Milton Johnson

Name: R. Milton Johnson

Title: Executive Vice President and Chief Financial Officer

HERCULES HOLDING II, LLC

By: /s/ Chris Gordon

Name: Chris Gordon

Title: President

BAIN CAPITAL PARTNERS, LLC

By: /s/ Stephen G. Pagliuca

Name: Stephen G. Pagliuca 
Title: Managing Director

KOHLBERG KRAVIS ROBERTS \& CO. L.P.

By: KKR \& CO. LLC, its general partner

By: /s/ Michael W. Michelson

Name: Michael W. Michelson

Title: Member

MERRILL LYNCH GLOBAL PARTNERS, INC.

By: /s/ George A. Bitar

Name: George A. Bitar

Title: Managing Director

IN WITNESS WHEREOF, each of the undersigned has duly executed this Agreement (or $\backslash$ caused this Agreement to be executed on its behalf by its officers or representatives as thereunto duly authorized) under seal as of the date that above written.

HCA INC.

By:

Name:

Title:

BAIN CAPITAL PARTNERS, LLC

By:

Name:

Title:

KOHLBERG FRAVIS ROBERTS CO, L.P.

By: KKR \& CO. LLC, its general partner

By:

Name:

Title:

MERRILL LYNCH GLOBAL PARTNERS, INC.

By:

Name: Nathan Thorne

Title: President

By: /s/ Thomas F. Frist, Jr.

Name: Dr. Thomas F. Frist, Jr.

By: /s/ Patricia F. Elcan

Name: Patricia F. Elcan 
By: /s/ William R. Frist

Name: William R. Frist

By: /s/ Thomas F. Frist III

Name: Thomas F. Frist III 


\section{Online Appendix D: Management Service Agreement of West Corp.}

This MANAGEMENT AGREEMENT (this "Agreement") is entered into as of October 24, 2006 by and among (i) Omaha Acquisition Corp. ("Newco"), a Delaware corporation, (ii) West Corporation, a Delaware corporation (the "Company"), (iii) Quadrangle Advisors II LLC, a Delaware limited liability company ("Quadrangle"), and (iv) THL Managers VI, LLC, a Delaware limited liability company (“THL" and, together with Quadrangle, the "Managers").

WHEREAS, Newco has been formed for the purpose of effectuating a leveraged recapitalization transaction (the "Transaction") involving the Company pursuant to that certain Agreement and Plan of Merger, dated as of May 31 , 2006 (the "Merger Agreement"), by and between Newco and the Company, WHEREAS, it is contemplated that on or about the date hereof, as part of the Transaction, Newco will be merged (the "Merger") with and into the Company on the terms and subject to the conditions of the Merger Agreement; WHEREAS, to enable Newco and the Company to engage in the Transaction and related financing and other transactions, the Managers have provided the following financial advisory services (collectively, "Financial Advisory Services"): (i) advice, analysis and assistance with due diligence and other investigatory matters related to the Company, its subsidiaries and the industries in which they operate, (ii) structural advice and assistance with the negotiation of debt financing including senior debt facilities, (iii) arrangement and negotiation of senior executive management incentive arrangements and (iv) other advisory services; and WHEREAS, the Company desires to retain the Managers to provide certain management and advisory services to the Company and its subsidiaries (the Company and its subsidiaries being referred to herein collectively as the "West Companies"), and the Managers are willing to provide such services on the terms set forth below. NOW THEREFORE, in consideration of the mutual covenants contained herein, the parties hereto, intending to be legally bound, hereby agree as follows:

1. Services. Each of the Managers hereby agrees that it will provide the following consulting and management advisory services to the West Companies: (a) advice in connection with the negotiation and consummation of agreements, contracts, documents and instruments necessary to provide the West Companies with financing on terms and conditions satisfactory to the West Companies; (b) financial, managerial and operational advice in connection with day-to-day operations, including, without limitation, advice with respect to the development and implementation of strategies for improving the operating, marketing and financial performance of the West Companies; (c) advice in connection with financing, acquisition, disposition, merger, business combination and change of control transactions involving any of the West Companies (however structured); and (d) such other services (which may include financial and strategic planning and analysis, consulting services, human resources and executive recruitment services and other services) as such Manager and the West Companies may from time to time agree in writing.

Each of the Managers will devote such time and efforts to the performance of services contemplated hereby as such Manager deems reasonably necessary or appropriate; provided, however, that no minimum number of hours is required to be devoted by the Managers on a weekly, monthly, annual or other basis. The West Companies acknowledge that each of the Managers' services are not exclusive to any of the West Companies and that each Manager will render similar services to other persons and entities. The Managers and the West Companies understand that the West Companies may, at times, engage one or more investment bankers or financial advisers to provide services in addition to, but not in lieu of, services provided by the Managers under this Agreement. In 
providing services to the West Companies, each Manager will act as an independent contractor and it is expressly understood and agreed that this Agreement is not intended to create, and does not create, any partnership, agency, joint venture or similar relationship and that no party has the right or ability to contract for or on behalf of any other party or to effect any transaction for the account of any other party.

\section{Payment of Fees.}

(a) The West Companies, jointly and severally, will pay to the Managers (or such affiliates as they may respectively designate), in consideration of the Managers providing the Financial Advisory Services, an aggregate transaction fee (the "Transaction Fee") in the amount of $\$ 40,000,000$, such fee being payable on the effective date of the Merger (the "Closing Date"). The Transaction Fee shall be divided between the Managers as follows:

Quadrangle: $\$ 6,889,425$

THL: $\$ 33,110,575$

(b) During the Term, the West Companies, jointly and severally, will pay to the Managers (or such affiliates as they may respectively designate), an aggregate annual periodic fee (the "Periodic Fee") of $\$ 4,000,000$ in exchange for the ongoing services provided by the Managers under this Agreement, such fee being payable by the Company quarterly in advance on or before the start of each calendar quarter; provided, however, that the Company will pay the Periodic Fee for the period from the date hereof through December 31, 2006 on the Closing Date. The Periodic Fee will be prorated for any partial period of less than three months, and will be divided between the Managers pro rata in proportion to the respective ownership interests (i.e., relative share ownership) in the Company held at the time by the investment funds affiliated with each Manager (provided that, for purposes of this Agreement, (a) Quadrangle Capital Partners II LP, Quadrangle Capital Partners II-A LP, Quadrangle Select Partners II LP and their respective Affiliated Funds will be deemed to be investment funds affiliated with Quadrangle; and (b) Thomas $H$. Lee Equity Fund VI, L.P., Thomas H. Lee Parallel Fund VI, L.P., Thomas H. Lee Parallel (DT) Fund VI, L.P., Thomas H. Lee Equity Fund VI Investors (West), L.P., Thomas H. Lee Coinvestment Partners, LP, THL Fund VI Bridge Corp., THL Parallel Fund VI Bridge Corp., THL DT Fund VI Bridge Corp., Putnam Investments Holdings, LLC and Putnam Investments Employees' Securities Company III LLC and their respective Affiliated Funds will be deemed to be investment funds affiliated with THL). In this Agreement, the term "Affiliated Funds" shall mean, with respect to any specified investment fund, any other investment fund that directly or indirectly controls, is controlled by or is under common control with such specified fund or that has the same general partner or primary investment advisor as such specified fund (or a general partner or primary investment advisor that controls, is controlled by or is under common control with the general partner or primary investment advisor of such specified fund). (c) During the Term, the Managers will advise the West Companies in connection with financing, acquisition, disposition and change of control transactions involving the West Companies or any of their respective direct or indirect subsidiaries (however structured), and the West Companies, jointly and severally, will pay to the Managers (or such affiliates as they may respectively designate) an aggregate fee (the "Subsequent Fee") in connection with each such transaction equal to one percent $(1 \%)$ of the gross transaction value of such transaction, and, in the case of an Initial Public Offering or a Change of Control (as defined in the Stockholders Agreement, dated on or about the date hereof, among the Company and its stockholders (the "Stockholders Agreement") an amount equal to the net present value (using a discount rate equal to the then prevailing yield on U.S. Treasury Securities of like maturity) of the Periodic Fees that would have been payable to such Managers (based on relative ownership interest in the Company by investment 
funds affiliated with the Managers as of the time immediately prior to such termination) with respect to the period from the date of such transaction until the seventh anniversary of such transaction, such fee to be due and payable for the foregoing services at the closing of such transaction. Each Subsequent Fee will be divided between the Managers pro rata in proportion to the relative ownership interest in the Company held at the time of such transaction by the investment funds affiliated with each Manager. Each payment made pursuant to this Section 2 will be paid by wire transfer of immediately available federal funds to the accounts specified on Schedule 1 hereto, or to such other account(s) as the Managers may specify to the Company in writing prior to such payment.

3. Term. This Agreement will continue in full force and effect until December 31, 2016; provided that this Agreement shall be automatically extended each December 31 for an additional year unless the West Companies or both of the Managers provide written notice of their desire not to automatically extend the term of this Agreement to the other parties hereto at least 90 days prior to such December 31; and provided further, however, that (a) the Managers may, if both agree to do so, cause this Agreement to terminate at any time and (b) this Agreement will terminate automatically immediately prior to an Initial Public Offering or a Change of Control (each as defined in the Stockholder Agreement) unless the Company and both of the Managers determine otherwise (the period on and after the date hereof through the termination hereof being referred to herein as the "Term"). In the event of a termination of this Agreement, the West Companies will, jointly and severally, pay each of Quadrangle and THL (or such affiliates as they may respectively designate) (i) all unpaid Periodic Fees (pursuant to Section 2(b) above), Subsequent Fees (pursuant to Section 2(c) above) and expenses (pursuant to Section 4(a) below) due with respect to periods prior to the date of termination plus (ii) in the event of a termination pursuant to clause (a) above that does not otherwise require payment of an equivalent fee pursuant to Section 2(c) above, a termination fee in an amount equal to the net present value (using a discount rate equal to the then yield on U.S. Treasury Securities of like maturity) of the Periodic Fees that would have been payable to such Manager (based on relative ownership interest in the Company held by investment funds affiliated with the Managers as of the time immediately prior to such termination) with respect to the period from the date of termination until the seventh anniversary of such termination. The obligation to pay that fee and the provisions of Sections 4, 5, 6, 7, 8, 9, 10, 11 and 12 of this Agreement will all survive any termination of this Agreement.

4. Expenses; Indemnification.

(a) Expenses. The West Companies will, jointly and severally, pay on demand all Reimbursable Expenses. As used herein, "Reimbursable Expenses" means all (i) expenses incurred or accrued prior to the Closing Date by any of the Managers or their affiliates in connection with this Agreement, the Transaction or any related transactions, consisting of their respective out-of-pocket expenses for travel and other incidentals in connection with such transactions (including, without limitation, all air travel (by first class on a commercial airline or by charter, as determined by the appropriate Manager) and other travel related expenses) and the out-of-pocket expenses and the fees and charges of (A) Ropes \& Gray LLP, (B) KPMG, LLC, (C) Steptoe \& Johnson LLP, (D) Bain \& Company, (E) The Law Offices of Clayton Marsh, Esq., (F) The Payne Firm, Inc., environmental consultants, (G) Cambridge Strategic Management Company, industry consultants, $(\mathrm{H})$ Marsh McClennan, insurance specialists, and (I) any other consultants or advisors, appraisal or valuation firms, information or exchange agents, or other entities retained by the Managers in connection with such transactions, (ii) reasonable out-of-pocket expenses incurred from and after the Closing Date relating to their affiliated funds' investment in, the operations of, or the services provided by the Managers to, the West Companies or any of their affiliates from time to time (including, without limitation, all air travel (by first class on 
a commercial airline or by charter, as determined by the appropriate Manager) and other travel related expenses), (iii) reasonable out-of-pocket legal expenses incurred by any Manager or its affiliates from and after Closing Date in connection with the enforcement of rights or taking of actions under this Agreement, under the West Companies' certificates of incorporation and bylaws, or under any subscription agreements, stockholders agreements, registration rights agreements, voting agreements or similar agreements entered into with any West Company in connection with investments in the Company and/or its subsidiaries (subject to any applicable limitations on expense reimbursement rights expressly set forth in such agreements) and (iv) expenses incurred from and after the Closing Date by the Managers and their affiliates which both Managers agree are properly allocable to the West Companies under this Agreement. (b) Indemnity and Liability. The West Companies, jointly and severally, will indemnify, exonerate and hold each of the Managers, and each of their respective partners, shareholders, members, affiliates, directors, officers, fiduciaries, managers, controlling Persons, employees and agents and each of the partners, shareholders, members, affiliates, directors, officers, fiduciaries, managers, controlling Persons, employees and agents of each of the foregoing (collectively, the "Indemnitees") free and harmless from and against any and all actions, causes of action, suits, claims, liabilities, losses, damages and costs and out-of-pocket expenses in connection therewith (including reasonable attorneys' fees and expenses) incurred by the Indemnitees or any of them before or after the date of this Agreement (collectively, the "Indemnified Liabilities"), as a result of, arising out of, or in any way relating to (i) this Agreement, the Transaction, any transaction to which a West Company is a party, or any other circumstances with respect to a West Company or (ii) operations of, or services provided by any of the Managers to, the West Companies, or any of their affiliates from time to time (including but not limited to any indemnification obligations assumed or incurred by any Indemnitee to or on behalf of the Company, or any of its accountants or other representatives, agents or affiliates) except for any such Indemnified Liabilities arising on account of such Indemnitee's gross negligence or willful misconduct. If and to the extent that the foregoing undertaking may be unavailable or unenforceable for any reason, the Company hereby agrees to make and to cause the West Companies to make the maximum contribution to the payment and satisfaction of each of the Indemnified Liabilities that is permissible under applicable law. For purposes of this Section 4(b), "gross negligence or willful misconduct" will be deemed to have occurred only if so found in a final non-appealable judgment of a court of competent jurisdiction to such effect, in which case to the extent any of the foregoing limitations is so determined to apply to any Indemnitee as to any previously advanced indemnity payments made by the West Companies, then such payments shall be promptly repaid by such Indemnitee to the West Companies. The rights of any Indemnitee to indemnification hereunder will be in addition to any other rights any such person may have under any other agreement or instrument referenced above or any other agreement or instrument to which such Indemnitee is or becomes a party or is or otherwise becomes a beneficiary or under law or regulation. None of the Indemnitees will in any event be liable to the West Companies or any of their affiliates for any act or omission suffered or taken by such Indemnitee that does not constitute gross negligence or willful misconduct. If the Indemnitees related to each of the Managers are similarly situated with respect to their interests in connection with a matter that may be an Indemnified Liability and such Indemnified Liability is not based on a Third-Party Claim, the Indemnitees may enforce their rights pursuant to this Section 4(b) with respect to such matter only with the consent of both Managers. In this Agreement, "Person" means any individual or corporation, association, partnership, limited liability company, joint venture, joint stock or other company, business trust, trust, organization, or other entity of any kind. A "Third-Party Claim" means any (i) claim brought by a Person other than a West Company, a Manager or any indemnified Person related to a Manager and (ii) any derivative claim brought in the name of a West Company that is initiated by a Person other than a Manager or any indemnified Person related to a Manager. 
5. Disclaimer and Limitation of Liability; Opportunities.

(a) Disclaimer; Standard of Care. None of the Managers makes any representations or warranties, express or implied, in respect of the services to be provided by any Manager hereunder. In no event will any of the Managers be liable to the West Companies or any of their affiliates for any act, alleged act, omission or alleged omission that does not constitute gross negligence or willful misconduct of such Manager as determined by a final, non-appealable determination of a court of competent jurisdiction. (b) Freedom to Pursue Opportunities. In recognition that each Manager and its respective Indemnitees currently have, and will in the future have or will consider acquiring, investments in numerous companies with respect to which each Manager or its respective Indemnitees may serve as an advisor, a director or in some other capacity, and in recognition that each Manager and its respective Indemnitees have myriad duties to various investors and partners, and in anticipation that the West Companies, on the one hand and each of the Managers (or one or more affiliates, associated investment funds or portfolio companies), on the other hand, may engage in the same or similar activities or lines of business and have an interest in the same areas of corporate opportunities, and in recognition of the benefits to be derived by the West Companies hereunder and in recognition of the difficulties that may confront any advisor who desires and endeavors fully to satisfy such advisor's duties in determining the full scope of such duties in any particular situation, the provisions of this Section 5(b) are set forth to regulate, define and guide the conduct of certain affairs of the West Companies as they may involve such Manager. Except as a Manager may otherwise agree in writing after the date hereof: (i) Such Manager and its respective Indemnitees will have the right: $(A)$ to directly or indirectly engage in any business (including, without limitation, any business activities or lines of business that are the same as or similar to those pursued by, or competitive with, the Company and its subsidiaries), (B) to directly or indirectly do business with any client or customer of the Company and its subsidiaries, (C) to take any other action that such Manager believes in good faith is necessary to or appropriate to fulfill its obligations as described in the first sentence of this Section 5(b), and (D) not to present potential transactions, matters or business opportunities to the West Companies or any of their subsidiaries, and to pursue, directly or indirectly, any such opportunity for itself, and to direct any such opportunity to another person. (ii) Such Manager and its respective Indemnitees will have no duty (contractual or otherwise) to communicate or present any corporate opportunities to the West Companies or any of their affiliates or to refrain from any actions specified in Section 5(b)(i), and the West Companies, on their own behalf and on behalf of their affiliates, hereby renounce and waive any right to require such Manager or any of its Indemnitees to act in a manner inconsistent with the provisions of this Section 5(b). (iii) None of such Manager, nor any of its Indemnitees will be liable to the West Companies or any of their affiliates for breach of any duty (contractual or otherwise) by reason of any activities or omissions of the types referred to in this Section 5(b) or of any such person's participation therein. (c) Limitation of Liability. In no event will any of the Managers or any of their Indemnitees be liable to the West Companies or any of their affiliates or either of the other Managers or their Indemnitees for any indirect, special, incidental or consequential damages, including, without limitation, lost profits or savings, whether or not such damages are foreseeable, or for any third party claims (whether based in contract, tort or otherwise), relating to the services to be provided by the Managers hereunder.

6. Assignment, etc. Except as provided below, no party hereto has the right to assign this Agreement without the prior written consent of each of the other parties. Notwithstanding the foregoing, (a) any Manager may assign all or part of its rights and obligations hereunder to any of its respective affiliates that provides services similar to those called for 
by this Agreement and (b) the provisions hereof for the benefit of Indemnitees other than the Managers themselves shall also inure to the benefit of such other Indemnitees and their successors and assigns.

7. Amendments and Waivers. No amendment or waiver of any term, provision or condition of this Agreement will be effective, unless in writing and executed by both Managers and the Company (or their respective successors);provided, that any Manager may individually agree to waive or reduce any fee to which it is entitled pursuant to this Agreement, and, unless otherwise directed by such Manager, such waived portion shall revert to the West Companies. No waiver on any one occasion will extend to or effect or be construed as a waiver of any right or remedy on any future occasion. No course of dealing of any person nor any delay or omission in exercising any right or remedy will constitute an amendment of this Agreement or a waiver of any right or remedy of any party hereto.

\section{Governing Law; Jurisdiction.}

(a) Choice of Law. This Agreement and all matters arising under or related to this Agreement will be governed by and construed in accordance with the domestic substantive laws of the State of New York without giving effect to any choice or conflict of law provision or rule that would cause the application of the domestic substantive laws of any other jurisdiction. (b) Consent to Jurisdiction. Each of the parties agrees that all actions, suits or proceedings arising out of, based upon or relating to this Agreement or the subject matter hereof will be brought and maintained exclusively in the federal and state courts of the State of New York, County of New York. Each of the parties hereto by execution hereof (i) hereby irrevocably submits to the jurisdiction of the federal and state courts in the State of New York, County of New York for the purpose of any action, suit or proceeding arising out of or based upon this Agreement or the subject matter hereof and (ii) hereby waives to the extent not prohibited by applicable law, and agrees not to assert, by way of motion, as a defense or otherwise, in any such action, suit or proceeding, any claim that it is not subject personally to the jurisdiction of the above-named courts, that it is immune from extraterritorial injunctive relief or other injunctive relief, that its property is exempt or immune from attachment or execution, that any such action, suit or proceeding may not be brought or maintained in one of the above-named courts, that any such action, suit or proceeding brought or maintained in one of the above-named courts should be dismissed on grounds of forum non conveniens, should be transferred to any court other than one of the above-named courts, should be stayed by virtue of the pendency of any other action, suit or proceeding in any court other than one of the abovenamed courts, or that this Agreement or the subject matter hereof may not be enforced in or by any of the abovenamed courts. Notwithstanding the foregoing, to the extent that any party hereto is or becomes a party in any litigation in connection with which it may assert indemnification rights set forth in this Agreement, the court in which such litigation is being heard will be deemed to be included in clause (i) above. Each of the parties hereto hereby consents to service of process in any such suit, action or proceeding in any manner permitted by the laws of the State of New York, agrees that service of process by registered or certified mail, return receipt requested, at the address specified in or pursuant to Section 10 is reasonably calculated to give actual notice and waives and agrees not to assert by way of motion, as a defense or otherwise, in any such action, suit or proceeding any claim that service of process made in accordance with Section 10 does not constitute good and sufficient service of process. The provisions of this Section 8 will not restrict the ability of any party to enforce in any court any judgment obtained in a federal or state court of the State of New York. (c) Waiver of Jury Trial. To the extent not prohibited by applicable law that cannot be waived, each of the parties hereto hereby waives, and covenants that it will not assert (whether as plaintiff, defendant, or otherwise), any right to trial by jury in any forum in respect of any issue, claim, demand, cause of action, action, suit or proceeding arising out of or based upon this Agreement or the subject matter hereof, in each 
case whether now existing or hereafter arising and whether in contract or tort or otherwise. Each of the parties hereto acknowledges that it has been informed by each other party that the provisions of this Section 8(c) constitute a material inducement upon which such party is relying and will rely in entering into this Agreement and the transactions contemplated hereby. Any of the parties hereto may file an original counterpart or a copy of this Agreement with any court as written evidence of the consent of each of the parties hereto to the waiver of its right to trial by jury.

9. Entire Agreement. This Agreement contains the entire understanding of the parties with respect to the subject matter hereof and supersedes any prior communication or agreement with respect thereto.

10. Notice. All notices, demands, and communications required or permitted under this Agreement shall be in writing and shall be effective if served upon such other party and such other party's copied persons as specified below to the address set forth for it below (or to such other address as such party shall have specified by notice to each other party) if (i) delivered personally, (ii) sent and received by facsimile or (iii) sent by certified or registered mail or by Federal Express, DHL, UPS or any other comparably reputable overnight courier service, postage prepaid, to the appropriate address as follows:

If to a West Company, to it at:

West Corporation

11808 Miracle Hills Drive

Omaha, Nebraska 68154

Facsimile: (402) 963-1211

Attention: General Counsel

with copies to:

Ropes \& Gray LLP

One International Place

Boston, Massachusetts 02110

Facsimile: (617) 951-7050

Attention: David C. Chapin \& Patrick Diaz

If to Quadrangle, to:

c/o Quadrangle Advisors II, LLC

375 Park Avenue

New York, New York 10152

Facsimile: (212) 418-1701

Attention: Joshua Steiner \& David Crosby

with copies to:

Ropes \& Gray LLP

One International Place

Boston, Massachusetts 02110

Facsimile: (617) 951-7050

Attention: David C. Chapin \& Patrick Diaz 
If to THL, to:

c/o Thomas H. Lee Partners

100 Federal Street

Boston, Massachusetts 02110

Facsimile: (617) 227-3514

Attention: Anthony DiNovi \& Soren Oberg

with copies to:

Ropes \& Gray LLP

One International Place

Boston, Massachusetts 02110

Facsimile: (617) 951-7050

Attention: David C. Chapin \& Patrick Diaz

Unless otherwise specified herein, such notices or other communications will be deemed effective, (a) on the date received, if personally delivered or sent by facsimile during normal business hours, (b) on the business day after being received if sent by facsimile other than during normal business hours, (c) one business day after being sent for overnight delivery by Federal Express, DHL or UPS or other comparably reputable delivery service and (d) five business days after being sent by registered or certified mail. Each of the parties hereto shall be entitled to specify a different address by giving notice as aforesaid to each of the other parties hereto.

11. Severability. If in any judicial or arbitral proceedings a court or arbitrator refuses to enforce any provision of this Agreement, then such unenforceable provision will be deemed eliminated from this Agreement for the purpose of such proceedings to the extent necessary to permit the remaining provisions to be enforced. To the full extent, however, that the provisions of any applicable law may be waived, they are hereby waived to the end that this Agreement be deemed to be valid and binding agreement enforceable in accordance with its terms, and in the event that any provision hereof is found to be invalid or unenforceable, such provision will be construed by limiting it so as to be valid and enforceable to the maximum extent consistent with and possible under applicable law.

12. Counterparts. This Agreement may be executed in any number of counterparts and by each of the parties hereto in separate counterparts, each of which when so executed will be deemed to be an original and all of which together shall constitute one and the same agreement.

IN WITNESS WHEREOF, each of the parties has caused this Agreement to be executed on its behalf as an instrument under seal as of the date first above written by its officer or representative thereunto duly authorized.

THE COMPANY: WEST CORPORATION

/s/ Thomas B. Barker

Name: Thomas B. Barker

Title: Chief Executive Officer

NEWCO: OMAHA ACQUISITION CORP. 
/s/ Jeff Swenson

Name: Jeff Swenson

Title: Vice President and Treasurer

QUADRANGLE: QUADRANGLE ADVISORS II LLC

/s/ Joshua L. Steiner

Name: Joshua L. Steiner

Title: Managing Member

THL: THL MANAGERS VI, LLC

By: Thomas H. Lee Partners, L.P., its managing member

By: Thomas H. Lee Advisors, LLC, its general partner /s/ Soren L. Oberg

Name: Soren L. Oberg

Title: Managing Director 


\section{Online Appendix E: Management Service Agreement of Simmons Co. (\#1)}

This Advisory Agreement (this "Agreement") is entered into as of the 29th day of October, 1998 by and between Simmons Holdings, Inc., a Delaware corporation (the "Holdings"), Simmons Company, a Delaware corporation (the "Company") and Fenway Partners, Inc., a Delaware corporation ("Fenway").

WHEREAS, Fenway has provided advisory and other services to Holdings and the Company in connection with the acquisition by funds affiliated with Fenway (the "Fenway Funds") of Simmons Holdings, Inc. (the "Acquisition") and the senior secured financing (the "Senior Financing") being provided for the Acquisition pursuant to a credit agreement dated on or about the date hereof by Goldman Sachs Credit Partners L.P. as joint lead arranger and syndication agent, Warburg Dillon Read LLC, as joint lead arranger, and UBS A.G., Stamford Branch as administrative agent and the lending institutions from time to time party thereto; WHEREAS, subject to the terms and conditions of this Agreement, Holdings and the Company desire to retain Fenway to provide certain management and advisory services to Holdings and the Company, and Fenway desires to provide such services;

NOW, THEREFORE, in consideration of the mutual covenants contained herein, and for other good and valuable consideration, the receipt and sufficiency of which are hereby acknowledged, the parties hereto, intending to be legally bound, hereby agree as follows:

1. SERVICES. Fenway hereby agrees that, during the term of this Agreement (the "Term"), it will: a. provide Holdings and the Company with advice in connection with the negotiation and consummation of agreements, contracts, documents and instruments necessary to provide the Company with senior secured financing from banks or other financial institutions or other entities on terms and conditions satisfactory to Holdings and the Company; and b. provide Holdings and the Company with financial, managerial and operational advice in connection with its day-to-day operations, including, without limitation: (i) advice with respect to the investment of funds; and (ii) advice with respect to the development and implementation of strategies for improving the operating, marketing and financial performance of Holdings and the Company.

2. PAYMENT OF FEES. The Company hereby agrees to:

a. pay to Fenway (or its designee) a fee in the amount of five million, one hundred thousand dollars $(\$ 5,100,000)$ and $379,119.069$ shares of Class B Common Stock of Holdings in connection with the structuring of the Acquisition and the Senior Financing, together with reimbursement of Fenway's reasonable out-of-pocket expenses incurred on behalf of the Company through the closing date in connection with the Acquisition, such fees and expenses being payable by the Company at the closing of the Acquisition; b. during the Term, pay to Fenway (or its designee) management fees as follows (subject to adjustment as provided below): for the Term of this Agreement, for each fiscal year, an amount equal to $1 / 4$ of $1 \%$ of net sales for the immediately preceding fiscal year or such other amount (or formula) as may be mutually agreed among Holdings, the Company and Fenway, in each case in exchange for the services provided to Holdings and the Company by Fenway, as more fully described in Section 1 of this Agreement, such fees being payable by Holdings and the Company quarterly in advance, the first such payment to be made at or promptly after the closing of the Acquisition; c. during the Term, allow Fenway to participate in the negotiation and consummation of any acquisition transactions by Holdings or the Company or any of its direct or indirect subsidiaries, and pay to Fenway (or an affiliate of Fenway designated by it) such customary fee as may be 
charged therefor by Fenway in connection therewith; provided, however, that in each case such fee shall not exceed the greater of (i) $\$ 1,000,000$ or (ii) one and one-half percent (1 1/2\%) of the aggregate transaction value (including liabilities assumed) and provided further that such fee shall be due and payable for the foregoing services at the closing of such transaction; and d. in the event of an acquisition or series of acquisitions of another business or businesses (whether by stock or asset purchase, merger or otherwise) wherein the acquired entities or businesses have an aggregate enterprise value in excess of $\$ 25,000,000$, thereafter, if appropriate under the circumstances, pay to Fenway an increase to the management fees payable pursuant to Section 2(b) above as is mutually agreed by the Company and Fenway (it being agreed that the amount of any such increase will be negotiated in good faith between the Company and Fenway). e. in the event of an initial public offering of Common Stock of Holdings or the Company, the parties agree to negotiate in good faith any adjustments to the fee as may be customary and appropriate based upon market conditions and the participation of Fenway in the business, financings and acquisition of Holdings and the Company (including, if applicable the termination of the Agreement); provided, however, that, nothing contained herein shall require Holdings or the Company to pay Fenway the present value of future payments under this Agreement through the term of this Agreement or any other fee in respect of such termination or adjustment. Each payment made pursuant to this Section 2 shall be paid by wire transfer of immediately available federal funds to such account(s) as Fenway may specify to the Company in writing prior to such payment.

3. TERM. This Agreement shall continue in full force and effect, unless and until terminated by mutual consent of the parties, for a minimum of ten years; and thereafter for so long as Fenway (or any successor or permitted assign, as the case may be) continues to carry on the business of providing services of the type described in Section 1 above; provided, however, that: a. either party may terminate this Agreement following a material breach of the terms of this Agreement by the other party hereto and a failure to cure such breach within 30 days following written notice thereof; b. this Agreement shall terminate automatically upon the earliest date upon which the Fenway Funds and their respective affiliates shall cease to retain the power to elect or cause the election of a majority of the board of directors of Holdings; and c. each of (i) the obligations of Holdings and the Company under Section 4 below, (ii) any and all accrued and unpaid obligations of Holdings and the Company owed under Section 2 above and (iii) the provisions of Sections 4(b) and 7 shall survive any termination of this Agreement to the maximum extent permitted under applicable law.

\section{EXPENSES; INDEMNIFICATION.}

a. Expenses. Whether or not the Acquisition or any of the other transactions contemplated by this Agreement or any other agreement executed in connection herewith shall be consummated, Holdings and the Company agree to pay on demand reasonable expenses incurred by Fenway and the Fenway Funds in connection with this Agreement, the Acquisition and such other transactions and all operations hereunder or otherwise incurred in connection with the Acquisition or the Company, including but not limited to: (i) the reasonable fees and disbursements of: (A) Ropes \& Gray, special counsel to Fenway and the Fenway Funds, (B) Ernst \& Young, accountant to Fenway and the Fenway Funds, and $(C)$ any other consultants or advisors retained by Fenway, the Fenway Funds or either of the parties identified in clauses (A) and (B) arising in connection therewith (including but not limited to the preparation, negotiation and execution of this Agreement and any other agreement executed in connection herewith or in connection with the Acquisition, the Senior Financing or the consummation of the other transactions contemplated hereby (and any and all amendments, modifications, restructurings and waivers, and exercises and preservations of rights and remedies hereunder or thereunder) and the operations of Holdings and the Company and any of its 
subsidiaries), and (ii) any out-of-pocket expenses incurred by Fenway in connection with the provision of services hereunder or the attendance at any meeting of the board of directors (or any committee thereof) of Holdings and the Company or any of its affiliates.

b. Indemnity and Liability. Holdings and the Company hereby agree to indemnify, exonerate and hold each of Fenway, and the Fenway Funds, and each of their respective partners, shareholders, affiliates, directors, officers, fiduciaries, employees and agents and each of the partners, shareholders, affiliates, directors, officers, fiduciaries, employees and agents of each of the foregoing (collectively, the "Indemnitees") free and harmless from and against any and all actions, causes of action, suits, losses, liabilities and damages, and expenses in connection therewith, including without limitation reasonable attorneys' fees and disbursements (collectively, the "Indemnified Liabilities"), incurred by the Indemnitees or any of them as a result of, or arising out of, or relating to the Acquisition, the execution, delivery, performance, enforcement or existence of this Agreement or the transactions contemplated hereby except for any such Indemnified Liabilities arising on account of such Indemnitee's gross negligence or willful misconduct, and if and to the extent that the foregoing undertaking may be unenforceable for any reason, Holdings and the Company hereby agrees to make the maximum contribution to the payment and satisfaction of each of the Indemnified Liabilities which is permissible under applicable law. None of the Indemnitees shall be liable to Holdings and the Company or any of its affiliates for any act or omission suffered or taken by such Indemnitee that does not constitute gross negligence or willful misconduct.

5. ASSIGNMENT, ETC. Neither party shall have the right to assign this Agreement; provided, however, that notwithstanding the foregoing prohibition, (a) Fenway may assign all or part of its rights and obligations hereunder to any affiliate of Fenway which provides services similar to those called for by this Agreement, in which event Fenway shall be released of all of its rights and obligations hereunder, and (b) the provisions hereof for the benefit of the Fenway Fund shall inure to the benefit of their successors and assigns.

6. AMENDMENTS AND WAIVERS. No amendment or waiver of any term, provision or condition of this Agreement shall be effective, unless in writing and executed by each of Fenway and the Company. No waiver on any one occasion shall extend to or effect or be construed as a waiver of any right or remedy on any future occasion. No course of dealing of any person nor any delay or omission in exercising any right or remedy shall constitute an amendment of this Agreement or a waiver of any right or remedy of any party hereto.

\section{MISCELLANEOUS.}

a. Choice of Law. This Agreement shall be governed by and construed in accordance with the domestic substantive laws of the State of New York without giving effect to any choice or conflict of law provision or rule that would cause the application of the domestic substantive laws of any other jurisdiction. b. Consent to Jurisdiction. Each of the parties agrees that all actions, suits or proceedings arising out of or based upon this Agreement or the subject matter hereof shall be brought and maintained exclusively in the federal and state courts of the State of New York. Each of the parties hereto by execution hereof (i) hereby irrevocably submits to the jurisdiction of the federal and state courts in the State of New York for the purpose of any action, suit or proceeding arising out of or based upon this Agreement or the subject matter hereof and (ii) hereby waives to the extent not prohibited by applicable law, and agrees not to assert, by way of motion, as a defense or otherwise, in any such action, suit or proceeding, any claim that it is not subject personally to the jurisdiction of the above-named courts, that it is immune from extraterritorial injunctive relief or other injunctive relief, that its property is exempt or immune from attachment or execution, that any such action, 
suit or proceeding may not be brought or maintained in one of the above-named courts, that any such action, suit or proceeding brought or maintained in one of the above-named courts should be dismissed on grounds of FORUM NON CONVENIENS, should be transferred to any court other than one of the above-named courts, should be stayed by virtue of the pendency of any other action, suit or proceeding in any court other than one of the above-named courts, or that this Agreement or the subject matter hereof may not be enforced in or by any of the above-named courts. Each of the parties hereto hereby consents to service of process in any such suit, action or proceeding in any manner permitted by the laws of the State of New York, agrees that service of process by registered or certified mail, return receipt requested, at the address specified in or pursuant to Section 9 is reasonably calculated to give actual notice and waives and agrees not to assert by way of motion, as a defense or otherwise, in any such action, suit or proceeding any claim that service of process made in accordance with Section 9 does not constitute good and sufficient service of process. The provisions of this Section $7(b)$ shall not restrict the ability of any party to enforce in any court any judgment obtained in a federal or state court of the State of New York. C. Waiver of Jury Trial. TO THE EXTENT NOT PROHIBITED BY APPLICABLE LAW WHICH CANNOT BE WAIVED, EACH OF THE PARTIES HERETO HEREBY WAIVES, AND COVENANTS THAT IT WILL NOT ASSERT (WHETHER AS PLAINTIFF, DEFENDANT, OR OTHERWISE), ANY RIGHT TO TRIAL BY JURY IN ANY FORUM IN RESPECT OF ANY ISSUE, CLAIM, DEMAND, CAUSE OF ACTION, ACTION, SUIT OR PROCEEDING ARISING OUT OF OR BASED UPON THIS AGREEMENT OR THE SUBJECT MATTER HEREOF, IN EACH CASE WHETHER NOW EXISTING OR HEREAFTER ARISING AND WHETHER IN CONTRACT OR TORT OR OTHERWISE. Each of the parties hereto acknowledges that it has been informed by each other party that the provisions of this Section 7 (c) constitute a material inducement upon which such party is relying and will rely in entering into this Agreement and the transactions contemplated hereby. Any of the parties hereto may file an original counterpart or a copy of this Agreement with any court as written evidence of the consent of each of the parties hereto to the waiver of its right to trial by jury.

8. MERGER/ENTIRE AGREEMENT. This Agreement contains the entire understanding of the parties with respect to the subject matter hereof and supersedes any prior communication or agreement with respect thereto.

9. NOTICE. All notices, demands, and communications of any kind which any party may require or desire to serve upon any other party under this Agreement shall be in writing and shall be served upon such other party and such other party's copied persons as specified below by personal delivery to the address set forth for it below or to such other address as such party shall have specified by notice to each other party or by mailing a copy thereof by certified or registered mail, or by Federal Express or any other reputable overnight courier service, postage prepaid, with return receipt requested, addressed to such party and copied persons at such addresses. In the case of service by personal delivery, it shall be deemed complete on the first business day after the date of actual delivery to such address. In case of service by mail or by overnight courier, it shall be deemed complete, whether or not received, on the third day after the date of mailing as shown by the registered or certified mail receipt or courier service receipt. Notwithstanding the foregoing, notice to any party or copied person of change of address shall be deemed complete only upon actual receipt by an officer or agent of such party or copied person.

If to Holdings or the Company, to it at:

Simmons Holdings, Inc.

Simmons Company 
One Concourse Parkway, Suite 600

Atlanta, Georgia 30328

Attention: Zenon S. Nie

With a Copy to:

Jones, Day, Reavis \& Pogue

Suite 3500

One SunTrust Plaza

Atlanta, Georgia 30308

Attention: Lizanne Thomas

If to Fenway, to it at:

Fenway Partners, Inc.

152 West 57th Street

New York, NY 10019

Attention: Richard C. Dresdale

With a Copy to:

Ropes \& Gray

One International Place

Boston, Massachusetts 02110

Attention: Lauren I. Norton

10. SEVERABILITY. If in any judicial or arbitral proceedings a court or arbitrator shall refuse to enforce any provision of this Agreement, then such unenforceable provision shall be deemed eliminated from this Agreement for the purpose of such proceedings to the extent necessary to permit the remaining provisions to be enforced. To the full extent, however, that the provisions of any applicable law may be waived, they are hereby waived to the end that this Agreement be deemed to be valid and binding agreement enforceable in accordance with its terms, and in the event that any provision hereof shall be found to be invalid or unenforceable, such provision shall be construed by limiting it so as to be valid and enforceable to the maximum extent consistent with and possible under applicable law.

\section{DISCLAIMER AND LIMITATION OF LIABILITY.}

a. Disclaimer. Fenway makes no representations or warranties, express or implied, in respect of the services to be provided by it hereunder. b. Standard of Care. In no event shall Fenway be liable to Holdings or the Company or any of its affiliates for any act, alleged act, omission or alleged omission on the part of Fenway that does not constitute gross negligence or wilful misconduct. c. Freedom to Pursue Opportunities, Etc. In anticipation that Holdings, the Company and Fenway (or one or more affiliates, associated investment funds or portfolio companies, or clients of Fenway) may engage in the same or similar activities or lines of business and have an interest in the same areas of corporate opportunities and in recognition of the difficulties which may confront any advisor who desires and endeavors fully to satisfy such advisor's duties in determining the full scope of such duties in any particular situation, the provisions of this clause (c) are set forth to regulate, define and guide the conduct of certain affairs of Holdings and the Company as they may involve Fenway. Except as Fenway may otherwise agree in writing after the date 
hereof: (i) Fenway shall have the right to, and shall have no duty (contractual or otherwise) not to, directly or indirectly: (A) engage in the same or similar business activities or lines of business as Holdings or the Company, including those competing with Holdings or the Company, and (B) do business with any client or customer of Holdings or the Company; (ii) Neither Fenway nor any officer, director, employee, partner, affiliate or associated entity thereof shall be liable to Holdings or the Company or its affiliates for breach of any duty (contractual or otherwise) by reason of any such activities of or of such person's participation therein; and (iii) In the event that Fenway acquires knowledge of a potential transaction or matter that may be a corporate opportunity for Holdings or the Company and Fenway or any other person, Fenway shall have no duty (contractual or otherwise) to communicate or present such corporate opportunity to Holdings or the Company and, notwithstanding any provision of this Agreement to the contrary, shall not be liable to Holdings or the Company or any of its affiliates for breach of any duty (contractual or otherwise) by reason of the fact that Fenway directly or indirectly pursues or acquires such opportunity for itself, directs such opportunity to another person, or does not present such opportunity to Holdings or the Company. d. Limitation of Liability. In no event will any party hereto be liable to the other for any indirect, special, incidental or consequential damages, including lost profits or savings, Iwhether or not such damages are foreseeable, or for any third party claims (whether based in contract, tort or otherwise), relating to the services to be provided by Fenway hereunder.

12. COUNTERPARTS. This Agreement may be executed in any number of counterparts and by each of the parties hereto in separate counterparts, each of which when so executed shall be deemed to be an original and all of which together shall constitute one and the same agreement.

IN WITNESS WHEREOF, each of the parties has caused this Agreement to be executed on its behalf as an instrument under seal as of the date first above written by its officer or representative thereunto duly authorized.

HOLDINGS: SIMMONS HOLDINGS, INC.

By /s/ Zenon S. Nie

Title: Chief Executive Officer

The Company: SIMMONS COMPANY

By /s/ Zenon S. Nie

Title: Chief Executive Officer

FENWAY: FENWAY PARTNERS, INC.

By /s/ Gregory P. Meredith

Title: Managing Director 


\section{Online Appendix F: Management Service Agreement of Simmons Co. (Deal \#2)}

This Management Agreement (this "AGREEMENT") is entered into as of the $19^{\text {th }}$ day of December, 2003, by and between Simmons Company, a Delaware corporation (the "COMPANY"), and THL Managers V, LLC, a Delaware limited liability company (the "SPONSOR"). WHEREAS, certain affiliates of Thomas H. Lee Partners, L.P. ("THL") have provided equity financing to the Company's indirect parent, THL Bedding Holding Company, a Delaware corporation ("HOLDINGS"), pursuant to that certain Contribution Agreement dated as of December 19, 2003, by and among Holdings and the persons listed on the signatures pages thereto. WHEREAS, Holdings' indirect subsidiary, THL Bedding Company ("THL BEDDING") entered into that certain Stock Purchase Agreement by and among THL Bedding, Simmons Holdings, Inc. and the sellers party thereto, dated as of November 17, 2003, and THL Bedding entered into that certain ESOP Stock Sale Agreement by and among THL Bedding, Simmons Holdings, Inc. and State Street Bank and Trust Company, dated as of November 21, 2003, pursuant to which, as of the date hereof, THL Bedding acquired all of the outstanding shares of Simmons Holdings, Inc. (the "ACQUISITION"). WHEREAS, immediately following the Acquisition, THL Bedding merged with and into Simmons Holdings, Inc. and Simmons Holdings, Inc. merged with and into Simmons Company, with Simmons Company as the surviving entity. WHEREAS, the Sponsor has staff specifically skilled in corporate finance, strategic corporate planning, and other management skills and advisory services. WHEREAS, the Company will require the Sponsor's special skills and management advisory services in connection with its business operations and execution of its strategic plan. WHEREAS, the Sponsor is willing to provide such skills and services to the Company. NOW, THEREFORE, in consideration of the mutual covenants contained herein, and for other good and valuable consideration, the receipt and sufficiency of which are hereby acknowledged, the parties hereto, intending to be legally bound, hereby agree as follows:

\section{Services.}

The Sponsor hereby agrees that if, during the term of this Agreement (the "TERM"), the Company reasonably and specifically requests that the Sponsor provide the services set forth below and the Sponsor agrees to provide such services, the Sponsor or one of its affiliates will provide the following services to the Company and its subsidiaries: (a) advice in connection with the negotiation and consummation of agreements, contracts, documents and instruments related to the Company's finances or relationships with banks or other financial institutions; or (b) advice with respect to the development and implementation of strategies for improving the operating, marketing and financial performance of the Company, and other senior management matters related to the business, administration and policies of the Company. The Sponsor shall have no obligation to the Company as to the method or timing of services rendered hereunder, and the Company shall not have any right to dictate or direct the details of the performance of services by the Sponsor rendered hereunder. The parties hereto expressly acknowledge that the services to be performed hereunder by the Sponsor shall not include investment banking or other financial advisory services rendered by Sponsor or its affiliates to the Company in connection with any specific acquisition, divestiture, refinancing or recapitalization by the Company or any of its subsidiaries for which the Sponsor may be entitled to receive additional compensation by mutual agreement of the Company or its subsidiary and the Sponsor. This Agreement shall in no way prohibit the Sponsor or any of its affiliates or any of their respective partners (both general and limited), members (both managing and otherwise), officers, directors, employees, agents or representatives from engaging in other activities, whether or not competitive with any business of the Company of any of its affiliates. 
2. Payment of Fees. In exchange for the Sponsor's arrangement of the equity financing and agreement to provide the services set forth herein, the Company hereby agrees to pay to the Sponsor (or its designee) the following fees: (a) a transaction fee in connection with the transactions contemplated in the Stock Purchase Agreement payable at the Closing (as defined in the Stock Purchase Agreement) of \$20,000,000; and (b) a management fee (the "FEE") equal to the greater of (i) $\$ 1,500,000$ per year or (ii) $1.0 \%$ of Consolidated EBITDA (as defined in the Credit and Guaranty Agreement dated as of December 19, 2003 by and among the Lenders from time to time party thereto, Goldman Sachs Credit Partners L.P., UBS Securities LLC, Deutsche Bank A.G., Cayman Islands Branch, the Company and certain of the subsidiaries of the Company, as the same may be amended, modified, renewed, refunded, replaced or refinanced from time to time) before deducting the Fee payable pursuant to this Section 2(b) ("ADJUSTED EBITDA"), commencing at the Closing. The Fee shall be payable semi-annually in advance (based on the prior year's Adjusted EBITDA) on January 2nd and July 2nd of each year, with an adjustment of the Fee for any fiscal year payable promptly following the determination of Adjusted EBITDA for such fiscal year or on termination of this Agreement. The first installment of the Fee shall be payable at the Closing. The initial Fee shall be for the period through July 2,2004 and shall include a pro rata portion of the 2003 fiscal year based on the number of days in the 2003 fiscal year following the Closing. All references to "per annum" or "annual" herein refer to the fiscal year of the Company. Each payment made pursuant to this Section 2 shall be paid by wire transfer of immediately available funds to the accounts specified on Exhibit A attached hereto, or to such other account(s) as each Sponsor may specify in writing to the Company.

3. Term. This Agreement shall be effective as of the date hereof and shall continue in full force and effect, unless and until (a) terminated by the Sponsor, (b) terminated automatically on the date which the Sponsor and its affiliates no longer beneficially owns at least twenty percent (20\%) of the equity securities of Holdings, or (c) terminated by the Sponsor upon the consummation of any public offering of the equity securities of the Company or Holdings. Upon any termination of this Agreement, each of $(A)$ the obligations of the Company under Section 4 below, (B) any and all owed and unpaid obligations of the Company under Section 2 above and (C) the provisions of Section 7 shall survive any termination of this Agreement to the maximum extent permitted under applicable law. In the event that the Sponsor terminates this Agreement in accordance with clause (c) above of this Section, the Company agrees to pay the Sponsor a cash lump-sum termination fee equal to the net present value of the fees that would have been payable to such Sponsor (but for the termination hereof) pursuant to Section 2(b) hereof for a period of seven (7) years from the date of such termination calculated using a discount rate equal to the ten-year treasury rate on the date of such termination. Such termination fee shall be payable by wire transfer of immediately available funds within ten (10) days after the date of termination to the account specified on Exhibit A attached hereto, or to such other account(s) as the Sponsor may specify in writing to the Company. As used herein, the term "PERSON" shall be construed in the broadest sense and means and includes a natural person, a partnership, a corporation, an association, a joint stock company, a limited liability company, a trust, a joint venture, an unincorporated organization and any other entity and any federal, state, municipal, foreign or other government, governmental department, commission, board, bureau, agency or instrumentality, or any private or public court or tribunal.

4. Expenses; Indemnification.

(a) Expenses. In addition to the fees set forth in Section 2 hereof, the Company agrees to pay on demand all reasonable costs and expenses incurred by the Sponsor and their affiliates or any of them in connection with this Agreement and in connection with performing services hereunder including but not limited to air travel charged at 
charter equivalent rates, legal, consulting, out of pocket and other expenses, including but not limited to the fees and disbursements of Weil, Gotshal \& Manges LLP, counsel to the Sponsor, and any other consultants or advisors retained by the Sponsor or its respective counsel arising in connection therewith, including but not limited to the preparation, negotiation and execution of this Agreement, the performance of services hereunder (including, without limitation, fees and expenses of independent professionals, research, transportation and per diem costs). (b) Indemnity and Liability. The Company will indemnify and hold harmless the Sponsor, its affiliates and their respective partners (both general and limited), members (both managing and otherwise), officers, directors, employees, agents and representatives (each such Person being an "INDEMNIFIED PARTY") from and against any and all losses, claims, damages and liabilities, whether joint or several, expenses of any nature (including reasonable attorneys' fees and disbursements), judgments, fines, settlements and other amounts arising from any and all claims, demands, actions, suits or proceedings, whether civil, criminal, administrative, arbitral or investigative, in which an Indemnified Party was involved or may be involved, or threatened to be involved, as a party or otherwise (the "LIABILITIES"), related to, arising out of or in connection with the advisory and consulting services contemplated by this Agreement or the engagement of the Sponsor pursuant to, and the performance by the Sponsor of the services contemplated by, this Agreement, and any other action taken by an Indemnified Party on behalf of the Company in connection with this Agreement, whether or not pending or threatened, whether or not resulting in any liability and whether or not such action, claim, suit, investigation or proceeding is initiated or brought by the Company. The Company will reimburse any Indemnified Party for all reasonable costs and expenses (including reasonable attorneys' fees and expenses) as they are incurred in connection with investigating, preparing, pursuing, defending or assisting in the defense of any action, claim, suit, investigation or proceeding for which the Indemnified Party would be entitled to indemnification under the terms of the previous sentence, or any action or proceeding arising therefrom, whether or not such Indemnified Party is a party thereto, provided that, subject to the following sentence, the Company shall be entitled to assume the defense thereof at its own expense, with counsel satisfactory to such Indemnified Party in its reasonable judgment. Any Indemnified Party may, at its own expense, retain separate counsel to participate in such defense, and in any action, claim, suit, investigation or proceeding in which both the Company and/or one or more of its subsidiaries, on the one hand, and an Indemnified Party, on the other hand, is, or is reasonably likely to become, a party, such Indemnified Party shall have the right to employ separate counsel at the expense of the Company and to control its own defense of such action, claim, suit, investigation or proceeding if, in the reasonable opinion of counsel to such Indemnified Party, a conflict or potential conflict exists between the Company, on the one hand, and such Indemnified Party, on the other hand, that would make such separate representation advisable. The Company agrees that it will not, without the prior written consent of the applicable Indemnified Party, settle, compromise or consent to the entry of any judgment in any pending or threatened claim, suit, investigation, action or proceeding relating to the matters contemplated hereby (if any Indemnified Party is a party thereto or has been threatened to be made a party thereto) unless such settlement, compromise or consent includes an unconditional release of the applicable Indemnified Party and each other Indemnified Party from all liability arising or that may arise out of such claim, suit, investigation, action or proceeding. Provided the Company is not in breach of its indemnification obligations hereunder, no Indemnified Party shall settle or compromise any claim subject to indemnification hereunder without the consent of the Company. The Company will not be liable under the foregoing indemnification provision with respect to any Indemnified Party, to the extent that any loss, claim, damage, liability, cost or expense is determined by a court, in a final judgment from which no further appeal may be taken, to have resulted primarily from the gross negligence or willful misconduct by an Indemnified Party. If an Indemnified Party is reimbursed hereunder for any expenses, such reimbursement of expenses shall be refunded to the extent it is finally judicially determined that the 
Liabilities in question resulted primarily from the gross negligence or willful misconduct of such Indemnified Party. The Company agrees that if any indemnification sought by any Indemnified Party pursuant to this Section 4 is unavailable for any reason or is insufficient to hold the Indemnified Party harmless against any Liabilities referred to herein, then the Company shall contribute to the Liabilities for which such indemnification is held unavailable or insufficient in such proportion as is appropriate to reflect the relative benefits received (or anticipated to be received) by the Company, on the one hand, and the Indemnified Party, on the other hand, in connection with the transactions which gave rise to such Liabilities or, if such allocation is not permitted by applicable law, not only such relative benefits but also the relative faults of the Company, on the one hand, and the Indemnified Party, on the other hand, as well as any other equitable considerations, subject to the limitation that in any event the aggregate contribution by the Indemnified Parties to all Liabilities with respect to which contribution is available hereunder shall not exceed the fees actually received by the Sponsors in connection with the transaction which gave rise to such Liabilities (excluding any amounts paid as reimbursement of expenses).

5. Assignment, etc. Except as provided below, neither the Company nor the Sponsor shall have the right to assign this Agreement. The Sponsor acknowledges that its services under this Agreement are unique. Accordingly, any purported assignment by the Sponsor shall be void. Notwithstanding the foregoing, the Sponsor may assign all or part of its rights and obligations hereunder to any affiliate of such Sponsor which provides services similar to those called for by this Agreement.

6. Amendments and Waivers. No amendment or waiver of any term, provision or condition of this Agreement shall be effective, unless in writing and executed by the Sponsor and the Company. No waiver on any one occasion shall extend to or effect or be construed as a waiver of any right or remedy on any future occasion. No course of dealing of any Person nor any delay or omission in exercising any right or remedy shall constitute an amendment of this Agreement or a waiver of any right or remedy of any party hereto.

\section{Miscellaneous.}

(a) Choice of Law. This Agreement shall be governed by and construed in accordance with the domestic substantive laws of The Commonwealth of Massachusetts without giving effect to any choice or conflict of law provision or rule that would cause the application of the domestic substantive laws of any other jurisdiction. (b) Consent to Jurisdiction. Each of the parties agrees that all actions, suits or proceedings arising out of or based upon this Agreement or the subject matter hereof shall be brought and maintained exclusively in the federal and state courts of The Commonwealth of Massachusetts. Each of the parties hereto by execution hereof (i) hereby irrevocably submits to the jurisdiction of the federal and state courts in The Commonwealth of Massachusetts for the purpose of any action, suit or proceeding arising out of or based upon this Agreement or the subject matter hereof and (ii) hereby waives to the extent not prohibited by applicable law, and agrees not to assert, by way of motion, as a defense or otherwise, in any such action, suit or proceeding, any claim that it is not subject personally to the jurisdiction of the above-named courts, that it is immune from extraterritorial injunctive relief or other injunctive relief, that its property is exempt or immune from attachment or execution, that any such action, suit or proceeding may not be brought or maintained in one of the above-named courts, that any such action, suit or proceeding brought or maintained in one of the abovenamed courts should be dismissed on grounds of forum non conveniens, should be transferred to any court other than one of the above-named courts, should be stayed by virtue of the pendency of any other action, suit or proceeding in any court other than one of the above-named courts, or that this Agreement or the subject matter 
hereof may not be enforced in or by any of the above-named courts. Each of the parties hereto hereby consents to service of process in any such suit, action or proceeding in any manner permitted by the laws of The Commonwealth of Massachusetts, agrees that service of process by registered or certified mail, return receipt requested, at the address specified in or pursuant to Section 10 is reasonably calculated to give actual notice and waives and agrees not to assert by way of motion, as a defense or otherwise, in any such action, suit or proceeding any claim that service of process made in accordance with Section 10 does not constitute good and sufficient service of process. The provisions of this Section $7(b)$ shall not restrict the ability of any party to enforce in any court any judgment obtained in a federal or state court of The Commonwealth of Massachusetts. (c) Waiver of Jury Trial. TO THE EXTENT NOT PROHIBITED BY APPLICABLE LAW WHICH CANNOT BE WAIVED, EACH OF THE PARTIES HERETO HEREBY WAIVES, AND COVENANTS THAT IT WILL NOT ASSERT (WHETHER AS PLAINTIFF, DEFENDANT, OR OTHERWISE), ANY RIGHT TO TRIAL BY JURY IN ANY FORUM IN RESPECT OF ANY ISSUE, CLAIM, DEMAND, CAUSE OF ACTION, ACTION, SUIT OR PROCEEDING ARISING OUT OF OR BASED UPON THIS AGREEMENT OR THE SUBJECT HEREOF, IN EACH CASE WHETHER NOW EXISTING OR HEREAFTER ARISING AND WHETHER IN CONTRACT OR TORT OR OTHERWISE. Each of the parties hereto acknowledges that it has been informed by each other party that the provisions of this Section 7 (c) constitute a material inducement upon which such party is relying and will rely in entering into this Agreement and the transactions contemplated hereby. Any of the parties hereto may file an original counterpart or a copy of this Agreement with any court as written evidence of the consent of each of the parties hereto to the waiver of its right to trial by jury.

8. Independent Contractor. The parties agree and understand that the Sponsor is and shall act as an independent contractor of the Company in the performance of its duties hereunder. The Sponsor is not, and in the performance of its duties hereunder will not hold itself out as, an employee, agent or partner of the Company.

9. Merger/Entire Agreement. This Agreement contains the entire understanding of the parties with respect to the subject matter hereof and supersedes any prior communication or agreement with respect thereto.

10. Notice. All notices, demands, and communications of any kind which any party may require or desire to serve upon any other party under this Agreement shall be in writing and shall be served upon such other party and such other party's copied persons as specified below by personal delivery to the address set forth for it below or to such other address as such party shall have specified by notice to each other party or by mailing a copy thereof by certified or registered mail, or by Federal Express or any other reputable overnight courier service, postage prepaid, with return receipt requested, addressed to such party and copied persons at such addresses. In the case of service by personal delivery, it shall be deemed complete on the first business day after the date of actual delivery to such address. In case of service by mail or by overnight courier, it shall be deemed complete, whether or not received, on the third day after the date of mailing as shown by the registered or certified mail receipt or courier service receipt. Notwithstanding the foregoing, notice to any party or copied Person of change of address shall be deemed complete only upon actual receipt by an officer or agent of such party or copied person.

If to the Company, to it at:

Simmons Company

One Concourse Parkway, Suite 800 
Atlanta, Georgia 30328

Attn: Chief Financial Officer and General Counsel

Telecopier: 770-392-2565

If to Sponsor, to it at:

THL Managers V, LLC

c/o Thomas H. Lee Partners, L.P.

75 State Street

Boston, MA 02109

Attention: Mr. Scott A. Schoen, Mr. Todd Abbrecht, Mr. George Taylor

Telecopier: (617) 227-3514

with a copy to:

Weil, Gotshal \& Manges LLP

100 Federal Street

Boston, Massachusetts 02110

Attention: James Westra, Esq.

Telecopier: (617) 772-8333

11. Severability. If in any judicial or arbitral proceedings a court or arbitrator shall refuse to enforce any provision of this Agreement, then such unenforceable provision shall be deemed eliminated from this Agreement for the purpose of such proceedings to the extent necessary to permit the remaining provisions to be enforced. To the full extent, however, that the provisions of any applicable law may be waived, they are hereby waived to the end that this Agreement be, deemed to be a valid and binding agreement enforceable in accordance with its terms, and in the event that any provision hereof shall be found to be invalid or unenforceable, such provision shall be construed by limiting it so as to be valid and enforceable to the maximum extent consistent with and possible under applicable law.

12. Counterparts. This Agreement may be executed in any number of counterparts and by each of the parties hereto in separate counterparts, each of which when so executed shall be deemed to be an original and all of which together shall constitute one and the same agreement.

13. Headings. All descriptive headings in this Agreement are inserted for convenience only and shall be disregarded in construing or applying any provision of this Agreement.

14. Prevailing Party. If any legal action or other proceedings is brought for a breach of this Agreement or any of the warranties herein, the prevailing party shall be entitled to recover its reasonable attorneys' fees and other costs incurred in bringing such action or proceeding, in addition to any other relief to which such party may be entitled.

IN WITNESS WHEREOF, each of the parties has caused this Agreement to be executed on its behalf as an instrument under seal as of the date first above written by its officer or representative thereunto duly authorized.

SIMMONS COMPANY

By: /s/ William S. Creekmuir

Name: William S. Creekmuir 
Title: Executive Vice President and CFO

THL MANAGERS V, LLC

By: Thomas H. Lee Partners, L.P., its Managing Member

By: THL Equity Advisors V, L.P., its General Partner

By: /s/ Scott A. Schoen

Name: Scott A. Schoen

Title: Managing Director 


\section{Online Appendix G: Fee Rebate Rates in Limited Partnership Agreements (LPA)}

\section{Data collection}

Rebate rates and computation rules are given in the Limited Partnership Agreements (LPAs), i.e. the contract signed between a GP and its LPs.

\section{Proprietary data sources}

One of the authors of this paper has a collection of complete LPAs obtained from a large German fund-offunds. ${ }^{6}$ To these LPAs we added 26 LPAs that were posted on the internet. ${ }^{7}$ In total we have 278 complete LPAs, which we list in Online Appendix Table 3. A minority of these LPAs cover US-focused LBO funds: 31 of the 375 GPs in our dataset are part of this list. We note several LBOs for which we know which GP sponsored the deal but it is unclear which of its funds were used. In that case we assume the fund to be the GP's US-LBO flagship fund whose vintage year was most recent to the LBO year. ${ }^{8}$ Coverage then increased to $16 \%$ of the 1044 GP-LBO observations (up from $12 \%$ without that assumption). In addition, we asked three academics who have collected LPAs. As a result of this request we obtained 1) 116 codified LPAs from a German fund-of-funds (apparently not the same one as ours and more US-LBO tilted than ours), bringing our coverage to $24 \%$ (of the 1044 GP-LBO observations), 2) 223 funds with fee information and rebates from a Swiss fund-of-funds, bringing our coverage to $31 \%$, and 3) Codified LPAs of the dataset that has been used in Braun, Jenkinson and Stoff (2015), bringing our coverage to $37 \%$. Additionally, we created an anonymous online survey and used our networks to publicise it. We used the list of 230 LPs who had contributed to a survey run by Marco DaRin and Ludovic Phalippou in $2008 .{ }^{9}$ Many people have changed positions, however, and only 100 email addresses were still valid. We asked the ILPA to circulate the survey among its members, but the ILPA was hesitant to do so due to possible member concerns. We asked practitioners at two PE events at our schools to fill in the survey. ${ }^{10}$ We also posted an appeal on Linkedln. ${ }^{11}$ Success was limited. One reason was that most of our network is Europe-based and our sample contains US-focused funds. We collected five responses covering ten funds we did not already have. Coverage reached $39 \%$.

\section{Public Data Sources}

We used information available online (GP websites, newspapers), SEC filings, and issued Freedom Of Information Act (FOIA) requests. This search yielded more observations than expected but data could

\footnotetext{
${ }^{6}$ The research project for which these data were collected has not materialized yet.

${ }^{7} \mathrm{https}: / /$ nakedcapitalism.net/documents.html

${ }^{8}$ We make this assumption for all the observations thereafter.

${ }^{9}$ Their paper using this data is published in the Journal Financial Intermediation.

${ }^{10} \mathrm{https} / / / q$ trial2016q4az1.az1.qualtrics.com/jfe/form/SV_4YF3gi1MLcffxC

${ }^{11}$ Respondents did it anonymously except for the European Investment Fund who gave us the rebate rate for two GPs in our dataset
} 
only be found for recent funds. After this step, coverage reaches $51 \%$. All but twelve observations from funds raised after 2007 are covered at this point. Details are provided below.

GP websites: Warburg Pincus and Hellman \& Friedman publicly state they do not charge any fees when investing on their own but might when co-investing, in which case they refund them entirely.

SEC fines: Four GPs were subject to an SEC investigation for their portfolio company fee policy. SEC filings detail the portfolio company fee offset policy of these firms (Apollo, Blackstone, Fenway Partners and WL Ross).

SEC Advisor Registration form (ADV Part 2): Since 2011, the SEC has required investment advisors to prepare brochures detailing their investment services and fee structures. Although many private equity firms do not disclose management fee rebates within these documents, we found 23 firms that do. Online Appendix Table 4 provides the list of GPs in our sample whose rebate rates are provided in their ADV Part II form.

Newspapers: One fund rebate rate was given in the Wall Street Journal (Online Appendix Table 5).

Publicly listed GPs: Publicly listed GPs may mention their rebate policy in their quarterly disclosures, but many only indicate an upper and lower bound rather than the exact rebate applied to each one of its funds. We used this information to verify that the rebate rates we had fell within those bounds. Only Oaktree Capital Management mentions its exact rebate rates. ${ }^{12}$ Publicly listed GPs also have an investor relation department that may answer requests for such information. We contacted Investor Relations at Ares, Apollo, KKR, Blackstone, Carlyle, Evercore, Fortress and Goldman Sachs to ask for their offset policy by fund. Two of these firms (Apollo and Fortress) responded positively and gave us the offset terms offered by each of their funds.

FOIA requests to public pension funds: We sent FOIA requests to the ten public pension funds in the US that invest the most in PE, asking for the rebate rates on their PE funds. They all replied that they cannot give this data except for Illinois State Board of Investment which gave us information for 4 funds (DLJ Investment Partners Fund II, Sprout Capital Fund IX, Warburg Pincus Private Equity Fund VIII and Riverside Fund IV).

\footnotetext{
${ }^{12}$ http://ir.oaktreecapital.com/phoenix.zhtml?c=212597\&p=irol-reportsOther
} 
Los Angeles Fire and Police Pension Fund minutes: From 2008, board meeting minutes mention fund fee rebates for the funds brought forward to the board for investment approval. This added 15 observations. $^{13}$

State of New Jersey, Department of the Treasury: From 2007, all private equity fund investment proposals presented at board meetings are listed online. ${ }^{14}$ We can download the 'memorandum', which includes a summary of the key terms and conditions, including the rebate policy for most funds. An example, for Onex IV, is shown in Online Appendix Table 6.

\section{Assumptions}

Among the GP-LBO observations still without information on fees net of rebate at this stage, 65 observations have as a sponsor a GP for which we know the rebate it applies to its previous or next flagship US LBO funds. We then study change in rebate rates across successive funds raised by the same GP in our dataset. We find that the rate is unchanged between two successive funds in $85 \%$ of the cases. As a result, if we have the rebate from the previous or follow-on fund by the same GP, we use that one as the prevailing rate for the fund under analysis (if both are available, we take the average). At this stage we have 597 observations for which we have the rebate rate, which means a $57 \%$ coverage.

In addition, there are 202 GP-LBO observations for which we do not know the rebate but no portfolio company fees were charged. For these, the rebate is irrelevant: both the post-rebate fee and the prerebate fee equal zero. This brings coverage of post rebate fees to $77 \%$.

Several missing observations of rebate rates at this stage are from GPs that do not raise external capital and are thus missing from the Preqin datasets as well. As a result, these missing points have a minor impact on the flow-fee analysis. The missing funds tend to be captive entities or asset owners. For example, Ontario teacher, CPPIB, and Alplnvest have two GP-LBO observations each. We could assume a $0 \%$ rebate in these cases since they do not rebate anything but we prefer to keep these observations out as missing since their situation is different to that of standard GPs, and, again, they are excluded anyway from the flow-fee analysis because they are not in Preqin. The situation is similar for captive funds, which may collect some of these fees but would keep them entirely. The coverage of portfolio company fee rebates within the Preqin universe reaches $75 \%$ and that of net portfolio company fees reaches $83 \%$.

\section{Caveats}

The rebate rates we retrieve are proxies for the actual rebate rates offered to given LP in a fund for several reasons. First, a higher rebate rates may be offered to selected LPs via side letters (see, e.g., Apollo filing ${ }^{15}$ ). In this case the rebate rate we find in LPAs is a lower bound. Second, LPAs vary in complexity and have different computation and exclusion rules. Fortunately, the cases that required

\footnotetext{
${ }^{13} \mathrm{https} / / /$ www.lafpp.com/board/meetings/2008-10-16/board-of-fire-and-police-pension-commissioners

${ }_{14}^{14} \mathrm{http}: / / \mathrm{www}$. state.nj.us/treasury/doinvest/alternativeinvestments.shtml

${ }^{15} \mathrm{https} / / /$ www.sec.gov/litigation/admin/2016/ia-4493.pdf
} 
assumptions were limited (covered a total of 100 observations and excluding these observations do not change any of our results).

\section{Discussion of other routes to collect rebate data}

LP annual reports: Some LPs show the amount of management fees paid in each of their funds each year. CalPERS used to do it; see Online Appendix Table 7. But to infer the rebate of each fund, we need to make three sets of assumptions: 1) assume the gross management fees payable: could say it is between $1.2 \%$ and $2 \%$ of capital committed during investment period to have a lower and upper bound; 2 ) assume that there are no management fee waivers; and 3) estimate the amount of portfolio company fees charged that year by that fund across all their portfolio companies. For example, consider Advent IV in Online Appendix Table 7. CalPERS website shows they committed 25 million in 2001 and the fee due that year is $\$ 250,000$, i.e. $1 \%$ of capital committed. We would need to know the amount of fees that were collected that year across all companies. Using five years of data on management fees (e.g. management fees went from $\$ 250,000$ to $\$ 338,000$ in 2005 etc.), we could make some inference but only if we know all the changes in underlying investment activity of that fund. We could do it with Capital IQ but estimation error compounds and we are concerned it would be too crude an estimate in the end. 


\section{Online Appendix Table 3: List of Funds for which we have complete LPAs}

\begin{tabular}{|c|c|}
\hline GP name & Fund name \\
\hline 3i Group & 3I Europartners Ivc Lp \\
\hline 3i Group & 3I Europartners V \\
\hline 75 Wall Street Associates & 75 Wall Street Associates \\
\hline Accel Europe & Accel Europe Associates L.P \\
\hline Advent International Corporation & Advent International GPE V \\
\hline Advent International Corporation & Advent International GPE VI \\
\hline Affinity & Affinity Asia Pacific Fund lii \\
\hline Affinity & Affinity Asia Pacific li \\
\hline Aisling Capital Partners & Aisling Capital lii \\
\hline Altor & Altor 2003 Fund \\
\hline Altor & Altor Fund li \\
\hline Altor & Altor Fund lii \\
\hline Anacap Financial Partners & Anacap Financial Partners \\
\hline Anacap Financial Partners & Anacap Financial Partners li \\
\hline Ap Cayman Partners & Ap Cayman Partners li \\
\hline Apax & Apax Europe Iv \\
\hline Apax & Apax Europe V \\
\hline Apax & Apax Europe Vi \\
\hline Apax & Apax Europe Vii \\
\hline Apax & Apax Europe Viii \\
\hline Apax & Apax Germany li \\
\hline Apax & Apax Israel li \\
\hline Atlantic Medical Associates & Atlantic Medical Capital \\
\hline Atlas Venture Associates & Atlas Venture Fund Vi \\
\hline Atlas Venture Associates & Atlas Venture Vii \\
\hline Atria Capital Partenaires & Atria Private Equity Fund Ii \\
\hline Atria Capital Partenaires & Atria Private Equity Fund lii \\
\hline Audax & Audax Private Equity Fund lii \\
\hline Audax & Audax Private Equity Fund Iv \\
\hline Bain Capital Partners & Bain Capital Asia Fund \\
\hline Bain Capital Partners & Bain Capital Fund Ix \\
\hline Bain Capital Partners & Bain Capital Fund X \\
\hline Bain Capital Partners & Bain Capital X Coinvestment Fund \\
\hline Bain Capital Partners & Bain Capital Europe Fund lii \\
\hline Bain Capital Partners & Bain Capital Fund Vii \\
\hline Bain Capital Partners & Bain Capital Fund Vii-E \\
\hline Bain Capital Partners & Bain Capital Fund Viii \\
\hline Bain Capital Partners & Bain Capital Fund Viii-E \\
\hline Barclays & Barclays Integrated Infrastructure Fund \\
\hline Barclays Private Equity & Barclays Private Equity European Fund li "A" \\
\hline Barclays Private Equity & Barclays Private Equity European Fund 'B' \\
\hline Barclays Private Equity & Barclays Private Equity European Fund lii "A" \\
\hline Baring Private Equity & The Barings Asia Private Equity Fund V \\
\hline Baring Private Equity & Baring Asia Private Equity Fund Iv \\
\hline Baring Private Equity & Baring Asia Private Equity Fund V \\
\hline Bbeif & Arcus European Infrastructure \\
\hline Bbeif & Bb European Infrastructure \\
\hline Bbof Slp & Bbof li Investors Lp(Bencis li) \\
\hline Benchmark & Benchmark Europe I \\
\hline Benchmark & Benchmark Europe li \\
\hline Benchmark & Benchmark Europe lii \\
\hline Blackstone & Blackstone Capital Partners V \\
\hline Blackstone & Blackstone Capital Partners Vi \\
\hline Brazos Equity & Brazos Equity Fund lii \\
\hline Bridgepoint & Bridgepoint Europe Iv 'A' L.P. \\
\hline Broadview Venture Capital & Kennet li \\
\hline
\end{tabular}




\begin{tabular}{|c|c|}
\hline Candover Investments & Candover 2008 Fund \\
\hline Capman & Capman Buyout Ix Fund A L.P. \\
\hline Carlyle & Carlyle Asia Growth Partners Iv L.P \\
\hline Carlyle & Carlyle Europe Partners lii L.P \\
\hline Carlyle & Carlyle Partners li \\
\hline Carlyle & Carlyle Japan International Partners li \\
\hline Castle Harlan Associates & Castle Harlan Partners li \\
\hline Catalyst General Partner & Catalyst Buyout Fund 2 \\
\hline Cb Offshore Equity & $\mathrm{Cb}$ Offshore Equity Fund Vii, L.P \\
\hline CDH Venture & Cdh Fund Iv L.P. \\
\hline CDH Venture & Cdh Venture Partners li L.P. \\
\hline Celerity Partners & Celerity Partners li, L.P. \\
\hline Century Park Advisors & Century Park Capital Partners li, L.P. \\
\hline Cerberus & Cerberus Levered Loan Opportunities Fund I \\
\hline Champ Buyout & Champ Buyout lii L.P \\
\hline Charles River & Charles River Partnership XI \\
\hline Charles River & Charles River Partnership Xii \\
\hline Charterhouse & Ccp Ix Lp No. 1 \\
\hline Chequers Partenaires & Chequers Capital Fcpr \\
\hline Chryscapital & Chryscapital V \\
\hline CID Venture Capital & Cid Greater China Venture Capital Fund Ii \\
\hline CID Venture Capital & Cid Greater China Venture Capital Fund lii \\
\hline CIE Management & Bcec Vii \\
\hline CIE Management & Bc European Capital Viii-8 \\
\hline Cinven Capital Management & Fifth Cinven Fund \\
\hline Cinven Capital Management & Cinven Fund No.1 Limited Partnership \\
\hline Cinven Capital Management & Second Cinven Fund No.1 Limited Partnership \\
\hline CITIC & Citic Capital China Partners li, L.P. \\
\hline Clarus Ventures & Clarus Life Sciences I L.P. \\
\hline Clarus Ventures & Clarus Life Sciences li L.P. \\
\hline Claudius & Galen Partners International lii \\
\hline Clayton, Dubilier \& Rice & Clayton, Dubilier \& Rice Fund Vi \\
\hline CLSA Private Equity Management & Aria Investment Partners \\
\hline Collinson Howe \& Lennox,Llc & Chl Medical Partners \\
\hline Court Square Capital & Court Square Capital Partners (Offshore) li \\
\hline Crescendo Ventures & Crescendo lii \\
\hline Crescendo Ventures & Crescendo Iv \\
\hline Crestview Partners & Crestview Partners li (Cayman) \\
\hline CVC Capital & Cvc Capital Partners Asia Pacific lii \\
\hline CVC Capital & Cvc European Equity Partners V \\
\hline CX Partners & Cx Partners Fund Alpha \\
\hline DAG Ventures & Dag Ventures li-Qp \\
\hline DBAG & Dbag Fund V \\
\hline Dolphin Communication & Dolphin Communications Parallel Fund \\
\hline Dolphin Communication & Dolphin Communications Fund li \\
\hline Dominion Management & Dominion Fund Iv \\
\hline Doughty Hanson \& Co & Doughty Hanson \& Co V \\
\hline Draper Fisher Jurvetson & Draper Fisher Jurvetson Fund Vii \\
\hline Efibanca & Star Bridge Social Responsible Fund \\
\hline Egeria Capital & Egeria li \\
\hline Egeria Capital & Egeria Private Equity Fund lii \\
\hline EQT & Eqt Iv (Uk) Limited \\
\hline EQT & Eqt Northen Europe \\
\hline Essex Woodlands & Essex Woodlands Health Ventures Fund Viii, \\
\hline Exponent Private Equity Partners & Exponent Private Equity Partners \\
\hline Financial Technology Management & Financial Technology Ventures li \\
\hline Frazier Healthcare & Frazier Healthcare Iv \\
\hline Gaillon & Pai Portfolio Debt Fund \\
\hline GEI Capital & Green Equity Investors lii \\
\hline
\end{tabular}




\begin{tabular}{|c|c|}
\hline Genstar Capital & Genstar Capital Partners Iv \\
\hline Genstar Capital & Genstar Capital Partnersv \\
\hline GI Manager & Gi Partners Fund lii-B \\
\hline Gilde & Gilde IV \\
\hline Gilde Equity Management & Gilde Equity Management II \\
\hline Global Infrastructure & Global Infrastructure Partners - A, L.P. \\
\hline Grand Avenue Capital Partners & Green Equity Investors li \\
\hline Granville Baird & Gb Duetschland Fund \\
\hline Greenbriar & Greenbriar Equity Fund \\
\hline Greenbriar & Greenbriar Equity Fund li \\
\hline Grotech Capital & Grotech Partners V \\
\hline Gs Infrastructure & Gs International Infrastructure Partners li \\
\hline Guernsey & Inflexion 2010 Buyout Fund LP \\
\hline GWW Partners & Galen Partners International li \\
\hline H.I.G. Advisors & H.I.G. Capital Partners lii \\
\hline H.I.G. Advisors & H.I.G. Capital Partners Iv \\
\hline H.I.G. Advisors & H.I.G. Bayside Debt \& Lbo Fund li \\
\hline H.I.G. Advisors & H.I.G. Bayside Opportunity Fund Ii \\
\hline Halder-Gimv & Halder-Gimv Germany li \\
\hline Harbourvest Partners & Harbourvest International Pe Partners III \\
\hline Harbourvest Partners & Harbourvest Partners Vi Partnership Fund \\
\hline Harvest & Harvest Partners lii \\
\hline Healthcap & Health Cap IV Bis \\
\hline Healthcap & Health Cap IV \\
\hline Hellman \& Friedman Investors & H\&F International Partners IV \\
\hline Hellman \& Friedman Investors & H\&F Capital Partners Partners V \\
\hline Hellman \& Friedman Investors & Hfcp Vi Aiv \\
\hline Hellman \& Friedman Investors & Hellman \& Friedman Capital Partners VII \\
\hline Herkules Private Equity & Herkules lii \\
\hline Hf Partners & Heritage Fund I \\
\hline Hf Partners & Heritage Fund li \\
\hline Hgcapital & Hgcapital 6 A \\
\hline Hicks, Muse, Tate \& Furst & Hmtf Equity Fund Iv \\
\hline Hicks, Muse, Tate \& Furst & Hmtf Equity Fund lii \\
\hline Hicks, Muse, Tate \& Furst & Hmtf Fund \\
\hline Hony Capital & Hony Capital Fund 2008 \\
\hline Horsley Bridge & Horsley Bridge International V \\
\hline $\mathrm{ICICI}$ Venture & India Advantage Fund S3 I \\
\hline Incline & Incline Equity Partners lii (Psers) \\
\hline Industri Kapital & Industri Kapital 2007 \\
\hline Investitori & Investitori Ass. Iv \\
\hline Investitori & Investitori Associati V \\
\hline Jiuding & Jiuding China Growth Fund \\
\hline Kelso \& Company & Kelso Investment Associates Vii \\
\hline Kelso \& Company & Kelso Investment Associates Viii \\
\hline KKR & Kkr 2006 Fund (Allstar) \\
\hline KKR & Kkr 2006 Fund (Invictus) \\
\hline KKR & Kkr European Fund li \\
\hline KKR & Kkr European Fund lii \\
\hline KMC & Kmc Capital Fund \\
\hline Knightsbridge & Knightsbridge Integrated Holdings IV \\
\hline Knightsbridge & Knightsbridge Allianze \\
\hline KPS Investors & Kps Special Situations Fund lii \\
\hline KRG Capital Management & Krg Capital Fund li \\
\hline L Capital & L Capital 2 \\
\hline Lake Capital & Lake Capital Partners \\
\hline Lime Rock & Lime Rock Partners lii \\
\hline Lime Rock & Lime Rock Partners Iv \\
\hline Lime Rock & Lime Rock Partners V \\
\hline
\end{tabular}




\begin{tabular}{|c|c|}
\hline Lincolnshire & Lincolnshire Equity Fund li \\
\hline Lindsay Goldberg & Lindsay Goldberg lii \\
\hline Littlejohn & Littlejohn Fund lii \\
\hline MHR & Mhr Institutional Partners lii \\
\hline Milestone & Milestone Partners Iv \\
\hline Monitor Clipper & Monitor Clipper Equity Partners li \\
\hline MPM Bioventures & Mpm Bioventures Parallel Fund \\
\hline MPM Bioventures & Mpm Bioventures li \\
\hline MPM Bioventures & Mpm Bioventures lii \\
\hline N+1 Capital Privado & $\mathrm{N}+1$ Private Equity Fund li Erisa, Fcr \\
\hline Navis & Navis Asia Fund V \\
\hline Nea Partners & New Enterprise Associates Vi \\
\hline Nea Partners & New Enterprise Associates Vii \\
\hline NEBO & Aac Capital Nebo Fund I \\
\hline NEBO & Aac Capital Nebo Fund li \\
\hline New Horizon & New Horizon Capital lii \\
\hline New Mountain & New Mountain Partners li \\
\hline New Mountain & New Mountain Partners lii \\
\hline New Silk Route & New Silk Route Pe Asia Fund \\
\hline Newbridge & Newbridge Asia Iv \\
\hline Newbury Ventures Partners & Newbury Ventures \\
\hline Newbury Ventures Partners & Newbury Ventures lii \\
\hline Newmargin Growth Ventures & Newmargin Growth Fund \\
\hline NMAS PE & Nmas Private Equity Fund Us No.1 \\
\hline Nordic Capital & Nordic Capital V \\
\hline Nordic Capital & Nordic Capital Vi \\
\hline Nordic Capital & Nordic Capital Vii \\
\hline Oak Hill & Oak Hill Capital Partners lii \\
\hline Onex & Onex Partners \\
\hline Onex & Onex Partners li \\
\hline Onex & Onex Partners lii \\
\hline Pacven Walden & Pacven Walden Ventures V \\
\hline PAl Management & Pai Europe lii-C Fcpr \\
\hline PAl Management & Pai Europe Iv-B \\
\hline PAl Management & Pai Europe V-1 \\
\hline Palladium & Palladium Equity Partners IV \\
\hline Perfectis $\mathrm{Pe}$ & Perfectis I \\
\hline Permira & Permira Europe lii \\
\hline Permira & Permira IV \\
\hline Platinum EP & Platinum Equity Capital Partners lii \\
\hline Platinum EP & Platinum Equity Capital Partners li \\
\hline Polish Enterprise Investors & Polish Enterprise Fund Vi \\
\hline PRISM & Prism Vetnure Partners I \\
\hline PV Equity Advisor & Preferential Equity Investors \\
\hline Riverside Capital & 2003 Riverside Capital Appreciation Fund \\
\hline Rreef Pan-European Infrastructure & Rreef Pan-European Infrastructure Feeder \\
\hline SAIF & Sb Asia Investment Fund li \\
\hline Santander Infrastructure Capital & Santander Infrastructure Fund li \\
\hline Sentinel Partners & Sentinel Capital Partners Iv-A \\
\hline Sequel Ventures Partners & Sequel Limited Partnership \\
\hline Shepherds Hill Partners & Shepherds Hill Fund \\
\hline Silverpeak Legacy & Silverpeak Legacy Limited Partners li \\
\hline Silverpeak Legacy & Silverpeak Legacy Limited Partners lii \\
\hline Sinergia & Sinergia Con Imprenditori \\
\hline Sixth Berkshire Associates & Berkshire Fund Vi \\
\hline Sterling & Sterling Investment Partners li \\
\hline Summit Partners & Summit Partners Subordinated Debt Fund Iv \\
\hline Summit Partners & Summit Partners Europe Pe Fund \\
\hline Summit Partners & Summit Partners Private Equity Fund Vii \\
\hline
\end{tabular}




\begin{tabular}{|l|l|}
\hline Summit Partners & Summit Ventures Vi-A \\
\hline Sun Capital & Sun Capital Partners IV \\
\hline Sun Capital & Sun Capital Partners V \\
\hline Swander Pace Capital & Spc Partners lii \\
\hline Swander Pace Capital & Spc Partners IV \\
\hline TA associates & Ta Associates Ap IV \\
\hline TA associates & Ta Subordinated Debt Fund \\
\hline TA associates & Ta Subordinated Debt Fund lii \\
\hline TA associates & Ta Atlantic And Pacific V \\
\hline TA associates & Ta Atlantic And Pacific Vi \\
\hline TA associates & Ta X \\
\hline TA associates & Ta Xi \\
\hline TB Partners & Trustbridge Partners lii \\
\hline TDR Capital & Tdr Capital li \\
\hline Terra Firma & Terra Firma Capital Partners li \\
\hline Terra Firma & Terra Firma Capital Partners lii \\
\hline Thayer & Thayer Equity Investors lii \\
\hline Thayer & Thayer Equity Investors IV \\
\hline Thomas H. Lee & Thomas H. Lee Parallel Fund V \\
\hline Thomas H. Lee & Thomas H. Lee Parallel Fund Vi \\
\hline Towerbrook & Towerbrook Investors li \\
\hline TPG & Tpg Opportunities Partners li (A) \\
\hline TPG & Top Npl (A) \\
\hline TPG & Tpg Asia V \\
\hline TPG & Tpg Biotechnology Partners li \\
\hline TPG & Tpg Biotechnology Partners lii \\
\hline TPG & Tpg Partners IV \\
\hline TPG & Tpg Partners V \\
\hline TPG & Tpg Partners Vi \\
\hline Trident Capital & Trident V \\
\hline Tullis Dickerson Capital & Tullis Dickerson Capital Focus li \\
\hline TVM & Tvm lii \\
\hline TVM & Tvm V Life Science Ventures \\
\hline VCP & Vision Capital Partners Vii Lp \\
\hline Vestar & Vestar Capital Partners IV \\
\hline Vista & Vista Equity Partners Fund lii \\
\hline VS\&A & Vs\&A Communications Partners li \\
\hline Walden & Walden Israel Ventures li \\
\hline Walden & Walden Israel Ventures lii \\
\hline Water Street & Water Street Capital Partners \\
\hline Water Street & Water Street Capital Healthcare Partners li \\
\hline Wellspring & Wellspring Capital Partners IV \\
\hline Wellspring & Wellspring Capital Partners V \\
\hline Wind Point & Wind Point Partners VII \\
\hline Windjammer Capital & Windjammer Senior Equity Fund Iv \\
\hline & \\
\hline
\end{tabular}




\section{Online Appendix Table 4: GPs that disclose rebate rates in their SEC Part 2 ADV statements}

\begin{tabular}{|c|c|}
\hline GP Name & Link to Part 2 ADV Disclosure \\
\hline ABRY Partners & $\begin{array}{l}\text { https://www.adviserinfo.sec.gov/IAPD/Content/Common/crd_iapd_Broch } \\
\text { ure.aspx?BRCHR_VRSN_ID=443090 }\end{array}$ \\
\hline ACON Investments & $\begin{array}{l}\text { https://www.adviserinfo.sec.gov//APD/Content/Common/crd_iapd_Broch } \\
\text { ure.aspx?BRCHR_VRSN_ID=444412 }\end{array}$ \\
\hline Brockway Moran \& Partners & $\begin{array}{l}\text { https://www.adviserinfo.sec.gov/IAPD/Content/Common/crd_iapd_Broch } \\
\text { ure.aspx?BRCHR_VRSN_ID=435964 }\end{array}$ \\
\hline Bruckmann Rosser Sherrill \& Co & $\begin{array}{l}\text { https://www.adviserinfo.sec.gov/IAPD/Content/Common/crd_iapd_Broch } \\
\text { ure.aspx?BRCHR_VRSN_ID=380910 }\end{array}$ \\
\hline Castle Harlan & $\begin{array}{l}\text { https://www.adviserinfo.sec.gov/IAPD/Content/Common/crd_iapd_Broch } \\
\text { ure.aspx?BRCHR_VRSN_ID=403425 }\end{array}$ \\
\hline Caxton-Iseman Capital & $\begin{array}{l}\text { https://www.adviserinfo.sec.gov/IAPD/Content/Common/crd_iapd_Broch } \\
\text { ure.aspx?BRCHR_VRSN_ID=377646 }\end{array}$ \\
\hline Cerberus Capital Management & $\begin{array}{l}\text { https://www.adviserinfo.sec.gov/IAPD/Content/Common/crd_iapd_Broch } \\
\text { ure.aspx?BRCHR_VRSN_ID=381233 }\end{array}$ \\
\hline Charlesbank Capital Partners & $\begin{array}{l}\text { https://www.adviserinfo.sec.gov/IAPD/Content/Common/crd_iapd_Broch } \\
\text { ure.aspx?BRCHR_VRSN_ID=370247 }\end{array}$ \\
\hline Farallon Partners & $\begin{array}{l}\text { https://www.adviserinfo.sec.gov//APD/Content/Common/crd_iapd_Broch } \\
\text { ure.aspx?BRCHR_VRSN_ID=371154 }\end{array}$ \\
\hline First Reserve Corporation & $\begin{array}{l}\text { https://www.adviserinfo.sec.gov//APD/Content/Common/crd_iapd_Broch } \\
\text { ure.aspx?BRCHR_VRSN_ID=444462 }\end{array}$ \\
\hline Golden Tree Asset Management & $\begin{array}{l}\text { https://www.adviserinfo.sec.gov//APD/Content/Common/crd_iapd_Broch } \\
\text { ure.aspx?BRCHR_VRSN_ID=435226 }\end{array}$ \\
\hline HBK Investments & $\begin{array}{l}\text { https://www.adviserinfo.sec.gov//APD/Content/Common/crd_iapd_Broch } \\
\text { ure.aspx?BRCHR_VRSN_ID=379441 }\end{array}$ \\
\hline Irving Place Capital & $\begin{array}{l}\text { https://www.adviserinfo.sec.gov/IAPD/Content/Common/crd_iapd_Broch } \\
\text { ure.aspx?BRCHR_VRSN_ID=402981 }\end{array}$ \\
\hline KSL Capital & $\begin{array}{l}\text { https://www.adviserinfo.sec.gov/IAPD/Content/Common/crd_iapd_Broch } \\
\text { ure.aspx?BRCHR_VRSN_ID=380255 }\end{array}$ \\
\hline Leonard Green \& Partners & $\begin{array}{l}\text { https://www.adviserinfo.sec.gov/IAPD/Content/Common/crd_iapd_Broch } \\
\text { ure.aspx?BRCHR_VRSN_ID=401048 }\end{array}$ \\
\hline Natural Gas Partners & $\begin{array}{l}\text { https://www.adviserinfo.sec.gov/IAPD/Content/Common/crd_iapd_Broch } \\
\text { ure.aspx?BRCHR_VRSN_ID=380457 }\end{array}$ \\
\hline Performance Equity Management & $\begin{array}{l}\text { https://www.adviserinfo.sec.gov/IAPD/Content/Common/crd_iapd_Broch } \\
\text { ure.aspx?BRCHR_VRSN_ID=414644 }\end{array}$ \\
\hline Peterson Partners & $\begin{array}{l}\text { https://www.adviserinfo.sec.gov//APD/Content/Common/crd_iapd_Broch } \\
\text { ure.aspx?BRCHR_VRSN_ID=381042 }\end{array}$ \\
\hline Simmons Associates & $\begin{array}{l}\text { https://www.adviserinfo.sec.gov/IAPD/Content/Common/crd_iapd_Broch } \\
\text { ure.aspx?BRCHR_VRSN_ID=382503 }\end{array}$ \\
\hline The Jordan Company & $\begin{array}{l}\text { https://www.adviserinfo.sec.gov//APD/Content/Common/crd_iapd_Broch } \\
\text { ure.aspx?BRCHR_VRSN_ID=439340 }\end{array}$ \\
\hline ValueAct Capital & $\begin{array}{l}\text { https://www.adviserinfo.sec.gov/lAPD/Content/Common/crd_iapd_Broch } \\
\text { ure.aspx?BRCHR_VRSN_ID=405221 }\end{array}$ \\
\hline Veronis Suhler Stevenson & $\begin{array}{l}\text { https://www.adviserinfo.sec.gov/lAPD/Content/Common/crd_iapd_Broch } \\
\text { ure.aspx?BRCHR_VRSN_ID=406961 }\end{array}$ \\
\hline Vestar Capital Partners & $\begin{array}{l}\text { https://www.adviserinfo.sec.gov/IAPD/Content/Common/crd_iapd_Broch } \\
\text { ure.aspx?BRCHR_VRSN_ID=381748 }\end{array}$ \\
\hline
\end{tabular}




\section{THE WALL STREET JOURNAL.}

This copy is for your personal, non-oommercial use only. To order presentation-feacy copies for digtobution to your colloagues, clionts or cuastomers visit hattpillawked joprints. $00 \mathrm{~m}$

hatp://bbas.ws; comvipivateequity/2010/01/04/crafsman-deats-ra-dropped-on-40orste $\rho$ '

PRIVATE EQUITY BEAT

\section{Craftsman Deals Vs. Dropped-On- Doorstep}

BY KEENAN SKELLY

Jan 4, 2010 4:48 pm ET

Clayton Dubilier \& Rice LLC has held a final close on its latest private equity offering, collecting approximately $\$ 5$ billion, said a person close to the firm.

The total missed the firm's original \$7.5 billion fund-raising goal, which was reduced to $\$ 5$ billion last March. But Clayton Dubilier \& Rice Fund VIII LP nonetheless raised more capital than its \$4 billion predecessor, which closed in 2006.

Investors said the firm managed to raise a substantial amount in part due to its emphasis on making operational improvements in complex situations. The New York firm also has historically generated solid deal flow from corporate divestitures, which have been common lately as companies strengthen their balance sheets by selling unwanted divisions.

"Commodity-like deals are those that are almost dropped on your doorstep all packaged and ready to close like we saw flooding the streets for the last three to five years," said a longtime CD\&R investor. "Craftsman deals, which CD\&R excels at, are complex, highly negotiated and structured, 'crafted' investments. These deals need relationship nurturing to obtain, unique financial skills to structure and plan, and operating talent to execute that plan."

In 2009, the firm announced three deals. In the largest, it took a big minority stake in cleaning company JohnsonDiversey Inc., a complex deal that kept the family owners in power but helped minority owner Unilever to sell down its ownership. It also invested $\$ 250$ million in publicly traded NCI Building Systems Inc. to help the company pay down debt, and agreed to purchase vehicle auctions company British Car Auctions Ltd. The deals brought Fund VIII, which has held multiple previous closings, to $20 \%$ invested.

In its year-end letter to investors, CD\&.R said it hopes to add at least one operating partner in 2010, in addition to Ed Liddy, who will rejoin the firm early this year after serving as chairman and chief executive of American International Group Inc. 
Limited partners in Fund VIII include Yale University, New York City Retirement Systems, South Carolina Retirement Systems, Adams Street Partners LLC, Teacher Retirement System of Texas, Ireland's National Pensions Reserve Fund and Partners Group.

The management fees for Fund VIII are $1.5 \%$ on commitments during the investment period, and $0.75 \%$ on invested capital thereafter. The GP's incentive hurdle rate is $8 \%$, and $80 \%$ of transaction, advisory and breakup fees, and $100 \%$ of directors' fees will be applied to offset the management fee. The GP commitment is $\$ 250$ million.

Share this: http:/lon.wsj.com/1ikcxcm

Copynght 2014 Dow Jones \& Company, inc. Al Rights Reserved

This copy is for your personal, non-commarcial use only. Diatribution and use of this material are gonemed by our Subscriber Agreement and by cosyright law. For non-personal use of to order multiph coples please contact Dow Jones Repints at 1-800-843-0008 or vest www.d jep rints.com. 


\section{Online Appendix Table 6: State of New Jersey, Department of the Treasury, Investment Memorandum for Onex IV}

Private Equity

INVESTMENT POLICY COMMITTEE REPORT TO THE STATE INVESTMENT COUNCIL

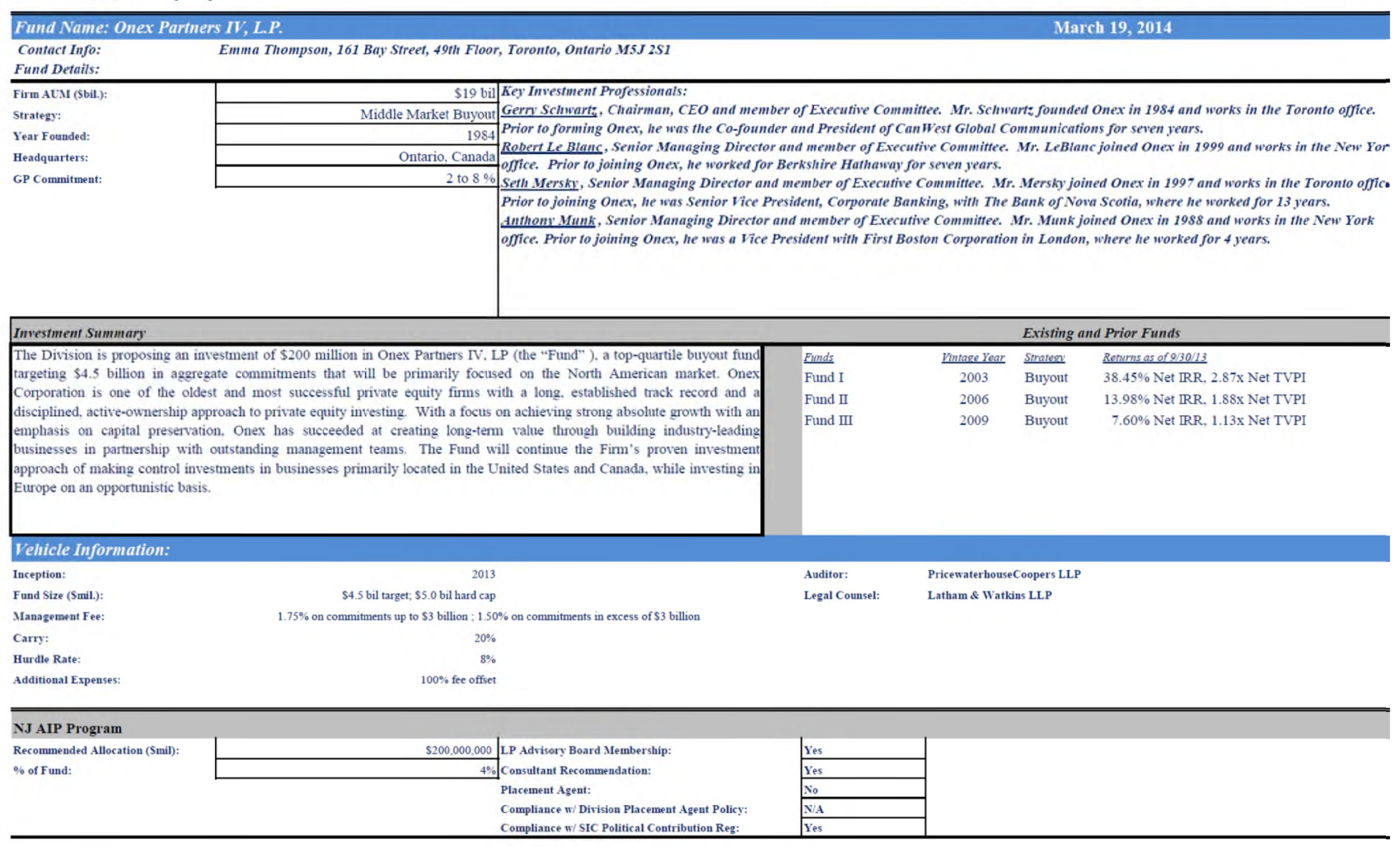




\section{Online Appendix Table 7: CalPERS reported management fees in 2004 and 2005}

(Actual Dollars)

\begin{tabular}{|c|c|}
\hline Fund Name & $\begin{array}{r}2004^{1} \\
\text { Fees \& Costs } \\
\end{array}$ \\
\hline 1818 Fund II, LP & $\$ 11,462$ \\
\hline ABS Capital Partners II, LP & 381,340 \\
\hline ABS Capital Partners III, LP & $1,128,219$ \\
\hline ABS Capital Partners IV, LP & $1,395,491$ \\
\hline Advent-Global Private Equity IV, LP & 258,074 \\
\hline Alta Biopharma Partners II, LP & $1,422,920$ \\
\hline Alta Biopharma Partners III, LP & 584,709 \\
\hline Alta Biopharma Partners, LP & $1,057,096$ \\
\hline Alta California Partners II, LP & $2,281,242$ \\
\hline Alta California Partners III, LP & $3,441,867$ \\
\hline Alta California Partners, LP & $2,322,401$ \\
\hline Alta Communications VI, LP & 167,273 \\
\hline Alta Communications VII, LP & $1,027,054$ \\
\hline Alta Communications VIII, LP & $1,909,170$ \\
\hline Alta Partners ACP IV, LP & 257,022 \\
\hline Alta V Limited Partnership & 4,006 \\
\hline American River Ventures I, LP & 936,820 \\
\hline APA Excelsior IV, LP & 140,900 \\
\hline APA German European Ventures, LP & 4,362 \\
\hline APAX CRIII & 675 \\
\hline APAX Ventures IV International Partners, LP & 1,460 \\
\hline Apollo Investment Fund III, LP & 930,964 \\
\hline Apollo Investment Fund IV, LP & 583,916 \\
\hline Apollo Investment Fund V, LP & 165,467 \\
\hline
\end{tabular}

\begin{tabular}{lr} 
Fund Name & Fees \& Costs \\
\hline Carlyle Asia Venture Partners II, LP & $\$ 579,718$ \\
Carlyle Europe Partners II, LP & 106,817 \\
Carlyle Europe Real Estate Partners, LP & 596,068 \\
Carlyle High Yield Partners IV, Lrd. & - \\
Carlyle Japan Partners, LP & 434,104 \\
Carlyle Partners II, LP & 217,350 \\
Carlyle Partners III, LP & $2,058,386$ \\
Carlyle Realty Qualified Partners III, LP & $2,678,235$ \\
Carlyle Strategic Partners, LP & 34,043 \\
Carlyle Venture Partners II, LP & $1,342,112$ \\
Carlyle/Riverstone Global Energy and Power Fund II, LP & $1,246,258$ \\
Clearstone Venture Partners III-A, LP & \\
Coller International Partners II, LP & 548,524 \\
Coller Internarional Partners III, LP & 886,379 \\
Coller International Partners IV, LP & $1,004,840$ \\
CVC European Equity Partners II, LP & 333,139 \\
CVC European Equiry Partners III, LP & $2,191,960$ \\
CVC European Equity Partners, LP & 128,539 \\
Dominion Fund IV, LP & 496,578 \\
Dominion Fund V, LP & 840,707 \\
Doughty Hanson \& Co. Fund II & - \\
Doyle \& Boissiere Fund I, LLC & 657,100 \\
DFJ Frontier Fund, LP & 548,048 \\
Dresdner Kleinwort Benson Emerging Europe & 261,807
\end{tabular}

\begin{tabular}{lr} 
& $2005^{1}$ \\
Fund Name & Fees \& Costs \\
\hline 1818 Fund II, LP & $\$ 31,112.00$ \\
Aberdare Ventures III, LP & $402,548.00$ \\
ABS Capital Partners II, LP & $427,409.00$ \\
ABS Capital Partners III, LP & $1,017,191.00$ \\
ABS Capital Partners IV, LP & $1,174,894.00$ \\
Advent-Global Private Equity IV, LP & $338,852.00$ \\
Advent-Global Private Equity V, LP & $427,250.00$ \\
Alta Biopharma Partners II, LP & $1,470,173.00$ \\
Aita Biopharma Partners III, LP & $752,338.00$ \\
Alta Biopharma Partners, LP & $971,229.00$ \\
Aita California Partners II, LP & $2,226,469.00$ \\
Alta California Partners III, LP & $3,407,818.00$ \\
Aita California Partners, LP & $2,071,882.00$ \\
Alta Communications VI, LP & $151,637.00$ \\
Alta Communications VII, LP & $1,031,695.00$ \\
Alta Communications VIII, LP & $1,881,698.00$ \\
Alta Partners ACP IV, LP & $456,607.00$ \\
Alta V. Limited Partnership & 5.058 .00 \\
American River Ventures I, LP & $1,167,826.00$ \\
APA Excelsior IV, LP & $108,226.00$ \\
APA German European Ventures, LP & $3,053.00$ \\
APAX CRIII & \\
APAX Ventures IV International Partners, LP & $4,764.00$ \\
Apollo Investment Fund III, LP & $756,938.00$ \\
Apollo Investment Fund IV, LP & $34,967.00$ \\
Apollo Investment Fund V, LP & $149,513.00$ \\
ArcLight Energy Partners Fund II, LP & $1,115,737.88$ \\
Ares Corporate Opportunities Fund, LP & $1,110,666.80$ \\
Asia Recovery Fund, LP & $226,551.00$ \\
Audax Private Equity II, LP & $72,879.86$ \\
Aurora Equity Partners II, LP & $32,943.00$
\end{tabular}

\begin{tabular}{lr} 
& $\mathbf{2 0 0 5}^{\mathbf{1}}$ \\
Fund Name & Fees \& Costs \\
\hline PCG Corporate Partners, LLC & $\$ 5,218,731.00$ \\
Candover 1994 Fund & $36,860.00$ \\
Candover 1997 Fund & $35,385.00$ \\
Candover 2001 Fund & $1,889,919.00$ \\
Carlyle Asia Partners, LP & $1,217,424.00$ \\
Carlyle Asia Growth Partners III, LP & $130,499.00$ \\
Carlyle Asia Venture Partners II, LP & $1,312,671.00$ \\
Carlyle Europe Partners II, LP & $1,032,951.00$ \\
Carlyle Europe Real Estate Partners, LP & $1,467,614.00$ \\
Carlyle High Yleld Partners IV, Ltd. & \\
Carlyle Japan Partners, LP & $461,189.00$ \\
Carlyle Mexico Partners, LP & $87,024.00$ \\
Carlyle Partners II, LP & $226,598.00$ \\
Carlyle Partners III, LP & $204,130.00$ \\
Carlyle Partners IV, LP & $3,006,997.00$ \\
Carlyle Realty Qualified Partners III, LP & $84,950.00$ \\
Carlyle Strategic Partners, LP & $479,687.00$ \\
Carlyle Venture Partners II. LP & $1,374,990.00$ \\
Carlyle/Riverstone Global Energy and Power Fund II, LP & $1,354,503.00$ \\
Central Valley Fund & $210,004.00$ \\
Clearstone Venture Partners III-A, LP & $8,514.00$ \\
Clearwater Capital Partners Fund II, LP & $3,592,705.00$ \\
Clessidra Capital Partners & $346,904.87$ \\
Coller International Partners II, LP & $640,760.00$ \\
Coller International Partners III, LP & $1,099,444.00$ \\
Coller International Partners IV, LP & $1,107,654.35$ \\
CVC European Equity Partners II, LP & $387,067.00$ \\
CVC European Equity Partners III, LP & $1,766,954.00$ \\
CVC European Equity Partners, LP & $45,810.00$ \\
CVC European Equity Partners IV, LP & $2,734,416.00$ \\
CVC Capital Partners Asia Pacific II & $1,270,196.00$
\end{tabular}

